\title{
Characterization of a catalyst-based conversion technique to measure total particulate nitrogen and organic carbon and comparison to a particle mass measurement instrument
}

\author{
Chelsea E. Stockwell ${ }^{1,2}$, Agnieszka Kupc ${ }^{1,2}$, Bartłomiej Witkowski ${ }^{1,2,3}$, Ranajit K. Talukdar ${ }^{1,2}$, Yong Liu ${ }^{4}$, \\ Vanessa Selimovic $^{5}$, Kyle J. Zarzana ${ }^{1,2}$, Kanako Sekimoto ${ }^{1,2}$, Carsten Warneke ${ }^{1,2}$, Rebecca A. Washenfelder ${ }^{1}$, \\ Robert J. Yokelson ${ }^{5}$, Ann M. Middlebrook ${ }^{1}$, and James M. Roberts ${ }^{1}$ \\ ${ }^{1}$ NOAA Earth System Research Laboratory (ESRL), Chemical Sciences Division, Boulder, CO 80305, USA \\ ${ }^{2}$ Cooperative Institute for Research in Environmental Sciences, University of Colorado, Boulder, CO 80309, USA \\ ${ }^{3}$ Faculty of Chemistry, University of Warsaw, al. Żwirki i Wigury 101, 02-089, Warsaw, Poland \\ ${ }^{4}$ Department of Chemistry, University of Colorado Denver, Denver, CO 80217, USA \\ ${ }^{5}$ Department of Chemistry, University of Montana, Missoula, MT 59812, USA
}

Correspondence: Chelsea E. Stockwell (chelsea.stockwell@ noaa.gov) and James M. Roberts (james.m.roberts@noaa.gov)

Received: 21 November 2017 - Discussion started: 2 January 2018

Revised: 20 March 2018 - Accepted: 26 April 2018 - Published: 14 May 2018

\begin{abstract}
The chemical composition of aerosol particles is a key aspect in determining their impact on the environment. For example, nitrogen-containing particles impact atmospheric chemistry, air quality, and ecological $\mathrm{N}$ deposition. Instruments that measure total reactive nitrogen $\left(\mathrm{N}_{\mathrm{r}}\right.$ $=$ all nitrogen compounds except for $\mathrm{N}_{2}$ and $\mathrm{N}_{2} \mathrm{O}$ ) focus on gas-phase nitrogen and very few studies directly discuss the instrument capacity to measure the mass of $\mathrm{N}_{\mathrm{r}^{-}}$ containing particles. Here, we investigate the mass quantification of particle-bound nitrogen using a custom $\mathrm{N}_{\mathrm{r}}$ system that involves total conversion to nitric oxide (NO) across platinum and molybdenum catalysts followed by $\mathrm{NO}-\mathrm{O}_{3}$ chemiluminescence detection. We evaluate the particle conversion of the $\mathrm{N}_{\mathrm{r}}$ instrument by comparing to mass-derived concentrations of size-selected and counted ammonium sulfate $\left(\left(\mathrm{NH}_{4}\right)_{2} \mathrm{SO}_{4}\right)$, ammonium nitrate $\left(\mathrm{NH}_{4} \mathrm{NO}_{3}\right)$, ammonium chloride $\left(\mathrm{NH}_{4} \mathrm{Cl}\right)$, sodium nitrate $\left(\mathrm{NaNO}_{3}\right)$, and ammonium oxalate $\left(\left(\mathrm{NH}_{4}\right)_{2} \mathrm{C}_{2} \mathrm{O}_{4}\right)$ particles determined using instruments that measure particle number and size. These measurements demonstrate $\mathrm{N}_{\mathrm{r}}$-particle conversion across the $\mathrm{N}_{\mathrm{r}}$ catalysts that is independent of particle size with $98 \pm 10 \%$ efficiency for 100-600 nm particle diameters. We also show efficient conversion of particle-phase organic carbon species to $\mathrm{CO}_{2}$ across the instrument's platinum catalyst followed by a nondispersive infrared (NDIR) $\mathrm{CO}_{2}$ detector. However, the application of this method to the atmosphere presents a
\end{abstract}

challenge due to the small signal above background at high ambient levels of common gas-phase carbon compounds (e.g., $\mathrm{CO}_{2}$ ). We show the $\mathrm{N}_{\mathrm{r}}$ system is an accurate particle mass measurement method and demonstrate its ability to calibrate particle mass measurement instrumentation using single-component, laboratory-generated, $\mathrm{N}_{\mathrm{r}}$-containing particles below $2.5 \mu \mathrm{m}$ in size. In addition we show agreement with mass measurements of an independently calibrated online particle-into-liquid sampler directly coupled to the electrospray ionization source of a quadrupole mass spectrometer (PILS-ESI/MS) sampling in the negative-ion mode. We obtain excellent correlations $\left(R^{2}=0.99\right)$ of particle mass measured as $\mathrm{N}_{\mathrm{r}}$ with PILS-ESI/MS measurements converted to the corresponding particle anion mass (e.g., nitrate, sulfate, and chloride). The $\mathrm{N}_{\mathrm{r}}$ and PILS-ESI/MS are shown to agree to within $\sim 6 \%$ for particle mass loadings of up to $120 \mu \mathrm{g} \mathrm{m}^{-3}$. Consideration of all the sources of error in the PILS-ESI/MS technique yields an overall uncertainty of $\pm 20 \%$ for these single-component particle streams. These results demonstrate the $\mathrm{N}_{\mathrm{r}}$ system is a reliable direct particle mass measurement technique that differs from other particle instrument calibration techniques that rely on knowledge of particle size, shape, density, and refractive index. 


\section{Introduction}

Aerosol particles are a key component of the atmospheric chemical environment as they have climate, human health, and ecosystem effects (Pöschl, 2005; IPCC, 2013). Measuring aerosol particle chemical composition is a challenging endeavor that has been the subject of a great deal of innovation in the past few decades (Jayne et al., 2000; Weber et al., 2001; Jimenez et al., 2009; Hallquist et al., 2009). The calibration of these instruments has evolved to better detect speciated composition. Still, there is a need for fundamental mass-based calibration techniques to place aerosol particle measurements firmly in the context of other atmospheric chemical observations.

Nitrogen $(\mathrm{N})$ compounds are major constituents of atmospheric aerosol and play a significant role in atmospheric chemistry, radiative balance, air quality, and $\mathrm{N}$ deposition in both terrestrial and aquatic ecosystems (Neff et al., 2002; Liao et al., 2003; Forster et al., 2007; Cornell, 2010; Xu and Penner, 2012; Park et al., 2014; Fuzzi et al., 2015). The relative contribution of $\mathrm{N}$ compounds, specifically particulate nitrate, to total atmospheric particle mass is expected to increase in the coming century due to a projected reduction in $\mathrm{SO}_{2}$ and increasing $\mathrm{NH}_{3}$ (Bauer et al., 2007; Bellouin et al., 2011; Hauglustaine et al., 2014; Li et al., 2015), and already dominates in some urban and agricultural environments (Haywood et al., 2008; Vieno et al., 2016). Excluding $\mathrm{N}$ species in deposition studies contributes to uncertainty in regional and global nitrogen budgets used to evaluate ecological, biogeochemical, and climate impacts (Jickells et al., 2013; Cornell, 2010; Cape et al., 2011). Measuring individual $\mathrm{N}$ species, classes of $\mathrm{N}$ compounds, or total $\mathrm{N}$ is challenging, and laboratory and field data are limited. For example, while there are a number of methods to measure inorganic $\mathrm{N}$ species, particulate organic $\mathrm{N}$ is more difficult to quantify with fewer sampling and measurement methods currently available for such a variety of compounds (Lin et al., 2010; Farmer et al., 2010; Lee et al., 2016). Measuring the total $\mathrm{N}$ mass of atmospheric particles will improve our understanding of their role in nitrogen cycles associated with sources such as agriculture or wildfires and processes such as photochemical oxidation.

Several techniques exist to measure total reactive nitrogen $\left(\mathrm{N}_{\mathrm{r}}\right)$, defined here as all atmospheric nitrogen excluding $\mathrm{N}_{2}$ and $\mathrm{N}_{2} \mathrm{O}$, which includes both gas (e.g., total odd nitrogen $\left(\mathrm{NO}_{y}\right), \mathrm{NH}_{3}$, amines, nitriles, nitrates) and particle-phase species (e.g., inorganic and organic $\mathrm{N}$ compounds). An established rapid-response robust technique for measuring $\mathrm{N}_{\mathrm{r}}$ involves thermal and catalytic conversion to nitric oxide (NO) with detection by ozone $\left(\mathrm{O}_{3}\right)$ chemiluminescence. The catalyst material, temperature, and sampling methods dictate the efficiency, time resolution, and speciation of measurements (Winer et al., 1974; Williams et al., 1998; Dunlea et al., 2007; Schwab et al., 2007; Benedict et al., 2017). The chemiluminescence detection technique has been used to measure
$\mathrm{NO}_{x}\left(\mathrm{NO}+\mathrm{NO}_{2}\right.$; Parrish and Fehsenfeld, 2000), total gasphase $\mathrm{N}_{\mathrm{r}}$ (e.g., Hardy and Knarr, 1982; Horstman, 1982), individual reactive nitrogen components (e.g., $\mathrm{NH}_{3}$; Breitenbach and Shelef, 1973; Saylor et al., 2010), or subsets of nitrogen compounds by removal of selected compounds using filters or denuders upstream (Prenni et al., 2014). Marx et al. (2012) completed the only study to explicitly report quantitative conversion of particle-bound $\mathrm{N}_{\mathrm{r}}$ for a limited number of species; however the results show a range of conversion efficiencies (78-142\%). Several other studies assume at least some (nonquantitative) particle conversion across their catalysts (Fahey et al., 1985, 1986; Prenni et al., 2014). To our knowledge, no study selectively isolates particle-phase reactive nitrogen to assess the particle-phase contribution to total nitrogen signals from individual sources or in their atmospheric measurement. Here we characterize the particulate $\mathrm{N}_{\mathrm{r}}$ conversion in our converter consisting of heated platinum and molybdenum catalysts followed by rapid chemiluminescence detection using common inorganic atmospheric $\mathrm{N}_{\mathrm{r}}$ species including $\left(\mathrm{NH}_{4}\right)_{2} \mathrm{SO}_{4}, \mathrm{NH}_{4} \mathrm{Cl}, \mathrm{NaNO}_{3}, \mathrm{NH}_{4} \mathrm{NO}_{3}$, and $\left(\mathrm{NH}_{4}\right)_{2} \mathrm{C}_{2} \mathrm{O}_{4}$. The application of the converter coupled with $\mathrm{NO}-\mathrm{O}_{3}$ chemiluminescence, hereafter referred to as the $\mathrm{N}_{\mathrm{r}}$ system, to quantitatively convert and measure the sum of $\mathrm{N}_{\mathrm{r}}$ particle mass was evaluated using mass concentrations determined using traditional particle instrument calibration methods.

Organic carbon species are major constituents of aerosol particles (Jimenez et al., 2009) and are responsible for some of the more important climate and health impacts of particles (Pöschl, 2005). Calibration of measurement systems for organic carbon species is a challenging task since there are thousands of possible compounds of differing sizes, functional groups, and therefore volatilities (Jimenez et al., 2016; Murphy, 2016a, b). A comprehensive mass-based technique for organic aerosol species would be a highly desirable addition to the current measurement technology. Theoretically, the high-temperature platinum catalyst in our system should convert carbon species to carbon dioxide $\left(\mathrm{CO}_{2}\right)$ in the presence of air. Conversion of volatile organic compounds (VOCs) to $\mathrm{CO}_{2}$ on high-temperature precious metal catalysts is a well-developed technique (see for example the Pt catalyst used in Veres et al., 2010). Total organic carbon measurements using similar catalysts (e.g., palladium on alumina) followed by reduction to methane have been used previously (Roberts et al., 1998; Maris et al., 2003). Platinum-based catalysts are widely used and have been shown to be more efficient than palladium in oxidation studies (Schwartz et al., 1971; Kamal et al., 2016). Here we characterize the conversion efficiency of particle-phase organic carbon across our Pt catalyst by direct measurements using a LI-COR nondispersive infrared (NDIR) $\mathrm{CO}_{2}$ analyzer. The current converter design coupled with both $\mathrm{NO}$ and $\mathrm{CO}_{2}$ detectors allows simultaneous measurements of $\mathrm{N}_{\mathrm{r}}$ and total carbon $\left(\mathrm{C}_{y}\right)$.

Many traditional particle instrument calibration methods involve measurements of particle properties by inertial, grav- 
itational, diffusional, electrical (e.g., sizing), thermal, or optical measurement devices (Chen et al., 2011). Generally, direct mass concentration calibration techniques involve offline analysis of filters or semi-real time measurements (e.g., PILS combined with ion chromatography). More rapid techniques directly measure number concentrations and particle sizes. However, these methods often require knowledge of aerosol properties (e.g., composition, shape, density, refractive index) and sampling parameters (e.g., volumetric flow rate, pressure, temperature, relative humidity) in order to determine mass concentrations. The $\mathrm{N}_{\mathrm{r}}$ system is an alternative that directly measures mass traced back to gas-phase calibration standards instead of relying on particle size, shape, or refractive index.

In order to demonstrate the application of the $\mathrm{N}_{\mathrm{r}}$ system to directly measure particle mass to calibrate particle mass measurement instrumentation, we compare mass concentrations measured by a new approach of directly coupling a particle-into-liquid sampler to the electrospray ionization source of a quadrupole mass spectrometer (PILS-ESI/MS) for online mass analysis of water-soluble aerosols. The PILS is an established technique developed to efficiently collect the water-soluble fraction of aerosol (Weber et al., 2001; Orsini et al., 2003; Sorooshian et al., 2006). Here, we couple the PILS with an independently calibrated electrospray interface followed by mass spectrometric detection to obtain online mass measurements of single-component, laboratorygenerated, $\mathrm{N}_{\mathrm{r}}$-containing aerosol that can be directly compared to the calibration obtained with the $\mathrm{N}_{\mathrm{r}}$ system.

In this work, we present the converter setup, system methodology, and evaluate the particle-conversion efficiency of a custom $\mathrm{N}_{\mathrm{r}}$ system for several atmospherically relevant $\mathrm{N}_{\mathrm{r}}$-containing particles. The conversion efficiency of the $\mathrm{N}_{\mathrm{r}}$ catalyst was evaluated by comparing the $\mathrm{N}_{\mathrm{r}}$ mass signal with the mass calculated from instrument calibration techniques that measure the particle number size distributions of laboratory-generated aerosols of known composition. We then show the quantitative conversion of organic carbon across the instrument's platinum catalyst followed by $\mathrm{CO}_{2}$ detection. Finally we compare particle mass directly measured using the PILS-ESI/MS with that measured using the $\mathrm{N}_{\mathrm{r}}$ instrument. The primary objectives are to characterize particle conversion in the $\mathrm{N}_{\mathrm{r}}$ system, and to investigate the capabilities of the $\mathrm{N}_{\mathrm{r}}$ system as a calibration instrument that directly measures particle mass concentration.

\section{Experimental details}

\subsection{Instrument descriptions}

\subsubsection{Total reactive nitrogen $\left(\mathrm{N}_{\mathbf{r}}\right)$ system}

Measurements of total reactive nitrogen, $\mathrm{N}_{\mathrm{r}}$, were accomplished by catalytic conversion to NO and detection of the
NO using a chemiluminescence instrument. This $\mathrm{NO}-\mathrm{O}_{3}$ chemiluminescence instrument is a custom-built version of the common atmospheric monitoring instrument (Williams et al., 1998) and is calibrated directly with gas-phase standards of NO. All the $\mathrm{N}_{\mathrm{r}}$ species were converted to NO or $\mathrm{NO}_{2}$ on a high-temperature catalyst, and the $\mathrm{NO}_{2}$ was subsequently converted to $\mathrm{NO}$ on a lower-temperature catalyst. The high-temperature catalyst system consisted of a quartz tube $(13 \mathrm{~mm} \mathrm{OD} \times 11 \mathrm{~mm} \mathrm{ID} \times 35 \mathrm{~cm} \mathrm{~L})$ packed with 36 platinum $(\mathrm{Pt})$ screens (Shimadzu part no. 630-00105) run at high temperature $\left(750^{\circ} \mathrm{C}\right)$, shown in Fig. 1 . The catalyst bed was confined to an $8 \mathrm{~cm}$ long section by dimples in the quartz tube, and that section was positioned so that the gas reaching it had been equilibrated to $750^{\circ} \mathrm{C}$, as confirmed by a thermocouple probe. The flow through the catalyst was set to 1 standard $\mathrm{L} \mathrm{min}^{-1}$ via a downstream flow controller. The Pt surface area was $126 \mathrm{~cm}^{2}$ and the residence time was $0.1 \mathrm{~s}$ at $83.3 \mathrm{kPa}$ and $750^{\circ} \mathrm{C}$. Platinum catalysts of this kind are also known to oxidize $\mathrm{NO}$ to $\mathrm{NO}_{2}$, which has been the source of problems with some previous systems that were designed to measure atmospheric ammonia $\left(\mathrm{NH}_{3}\right)$ (Schwab et al., 2007). In our system, the Pt catalyst is followed by a molybdenum oxide (MoOx) catalyst consisting of a solid molybdenum tube $(4.2 \mathrm{~mm} \mathrm{ID} \times 32 \mathrm{~cm} \mathrm{~L})$ operated at $450{ }^{\circ} \mathrm{C}$, to which an 8 standard $\mathrm{cm}^{3} \mathrm{~min}^{-1}$ flow of pure hydrogen was added to create a stable molybdenum oxide surface. Run in this manner, the MoOx surface did not require periodic treatment at higher temperatures under reducing conditions as described by Williams et al. (1998). The heated MoOx catalyst reduces the remaining $\mathrm{NO}_{2}$ to NO. The NO chemiluminescence detection scheme used for laboratory calibrations had a fundamental sensitivity between six and seven counts per part per trillion (pptv) and the detection limit determined by the background signal in zero air (ZA) was typically $15 \mathrm{pptv}$ $(4 \sigma)$ for a $1 \mathrm{~s}$ measurement. The operation of this instrument often required considerable de-tuning to keep the instrument count rates below the rollover point of the photoncounting electronics (approximately $5 \mathrm{MHz}$ ) for the particle concentrations generated; thus the detection limit was closer to $0.1 \mathrm{ppbv}$ (corresponding to $0.3 \mu \mathrm{g} \mathrm{m}^{-3}$ for aerosol nitrate).

\subsubsection{Total carbon $\left(C_{y}\right)$ system}

Measurements of total carbon $\left(\mathrm{C}_{y}\right)$ were accomplished by catalytic conversion to carbon dioxide $\left(\mathrm{CO}_{2}\right)$ and detection using a $\mathrm{CO}_{2}$ analyzer. The high-temperature $\left(750^{\circ} \mathrm{C}\right)$ platinum catalyst (Fig. 1) in the $\mathrm{N}_{\mathrm{r}}$ system should quantitatively convert carbon-containing species to $\mathrm{CO}_{2}$ in the presence of air. Gas-phase carbon conversion across similar precious metals has been studied extensively (see for example the Pt catalyst used in Veres et al., 2010). The total flow through the Pt catalyst was set to $\sim 1.5$ standard $\mathrm{L} \mathrm{min}^{-1}$ and was then split before the MoOx catalyst. In our sampling scheme 0.5 standard $\mathrm{L} \mathrm{min}^{-1}$ of flow was directed to a LI-COR 6251 (LI-6251; Lincoln, NE) $\mathrm{CO}_{2}$ analyzer, while the remaining 


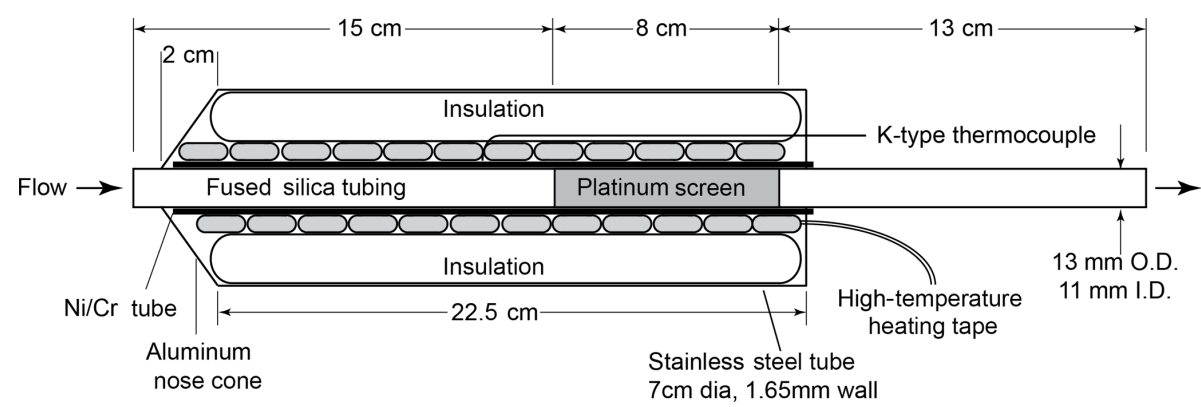

Figure 1. Diagram of the custom-built platinum catalyst system for the total reactive nitrogen instrument $\left(\mathrm{N}_{\mathrm{r}}\right)$ operated at $750{ }^{\circ} \mathrm{C}$. The outlet flow is followed by a molybdenum oxide catalyst before the custom $\mathrm{NO}-\mathrm{O}_{3}$ chemiluminescent instrument.

flow, 1 standard $\mathrm{L} \mathrm{min}^{-1}$, was directed through the MoOx catalyst and to the $\mathrm{NO}-\mathrm{O}_{3}$ chemiluminescence detector as detailed in Sect. 2.1.1. Run in this manner, the conversion of compounds that contain both $\mathrm{N}$ and $\mathrm{C}$ atoms can then be measured simultaneously using the $\mathrm{NO}-\mathrm{O}_{3}$ chemiluminescence detector and LI-6251 detector in parallel.

The LI-COR instrument was internally referenced to scrubbed $\mathrm{ZA}$. At ambient $\mathrm{CO}_{2}$ levels, it is challenging to retrieve reliable measurements since the signal relative to the background abundance of $\mathrm{CO}_{2}$ is small. In order to evaluate organic carbon conversion efficiency, our approach relies on using ultrapure air for aerosol generation and carrier gas flow; therefore ambient $\mathrm{CO}$ and $\mathrm{CO}_{2}$ are eliminated. The LI6251 was calibrated with sub-5 ppm $\mathrm{CO}_{2}$ standards (ScottMarrin Inc., Riverside, CA) in ultrapure air. Due to the low signal levels and the uncertainty of the low-concentration $\mathrm{CO}_{2}$ standards, the overall uncertainty of the $\mathrm{CO}_{2}$ measurements below $1 \mathrm{ppmv}$ presented in this work is $\pm 10 \%$ for $10 \mathrm{~s}$ averages.

\subsubsection{PILS-ESI/MS}

A schematic of the PILS-ESI/MS is shown in Fig. 2. The PILS (Brechtel Manufacturing Inc., Hayward, CA) was developed by Weber et al. (2001) and collects water-soluble aerosol compounds by growing particles into liquid droplets in a supersaturated water environment and then collecting the droplets. A detailed description of the PILS can be found in Sorooshian et al. (2006). The PILS is an established watersoluble aerosol collection technique that has been coupled with various mass analysis methods and was used previously by other laboratories in instrument evaluation studies (e.g., Drewnick et al., 2003; Takegawa et al., 2005; Canagaratna et al., 2007).

The PILS liquid output flow was set to $100 \mu \mathrm{L} \mathrm{min}^{-1}$ and was continuously mixed with an acetonitrile flow $\left(100 \mu \mathrm{L} \mathrm{min}^{-1}\right)$. The $1: 1$ volume mixture of acetonitrile and water was directed toward the custom electrospray ionization source (at $\sim 10 \mu \mathrm{L} \mathrm{min}^{-1}$ ) of a commercial quadrupole mass spectrometer (Balzers Instruments, QMG 422) operated in negative-ion mode for online analysis of selected water-soluble organic and inorganic compounds. The electrospray interface involved sample injection at ambient pressure through a fused silica capillary tip (30 $\mu \mathrm{M}$ ID) with a $2.5 \mathrm{~L} \mathrm{~min}^{-1} \mathrm{~N}_{2}$ sheath flow at a spray voltage of $-3.5 \mathrm{kV}$. The MS instrument was modified from the negative-ion proton-transfer chemical-ionization mass spectrometer (NIPT-CIMS) described in Veres et al. (2008). The flow tube was replaced with a stainless steel capillary inlet connected to the front region (I; shown in Fig. 2) held at 300 Pa. Ions were focused across this region using a planar direct current (DC) ion carpet (Anthony et al., 2014) mounted in front of the orifice leading to the second region (II). The ions were then accelerated through the collisional dissociation chamber (CDC) and collimated in the octopole ion guide at a total pressure of $\sim 1 \mathrm{~Pa}$ (region II). The ions were transferred to the quadrupole mass spectrometer (region III). The electron multiplier detector was maintained at a pressure of less than $6.6 \times 10^{-3} \mathrm{~Pa}$.

The ESI/MS was calibrated using volumetrically and gravimetrically prepared liquid-phase standards of the anions associated with the target compounds (e.g., $\mathrm{SO}_{4}^{2-}, \mathrm{NO}_{3}^{-}$, $\mathrm{Cl}^{-}$) (Sigma Aldrich, St. Louis, MO). Anion-specific calibration factors were calculated from linear least-square fits of multipoint calibration curves. The uncertainty in the slope resulted in a maximum uncertainty of $\sim 10 \%$ for the compounds tested. The ESI flow rate, solvent composition, analyte chemical properties, and matrix effects potentially impact the ionization and transmission efficiencies of compounds (Kostiainen and Kauppila, 2009). For these reasons, experiments were performed under similar, or as close to identical, conditions as the calibrations for instrument evaluation. The limits of detection for the anions measured with the PILS-ESI/MS were below $\sim 0.1 \mu \mathrm{g} \mathrm{m}^{-3}$ for the current system and sampling conditions. Sorooshian et al. (2006) discuss volatility losses in the PILS for several inorganic species and reported negligible loss with a collection efficiency of $\geq 96 \%$ for mass loadings of $\mathrm{Cl}^{-}, \mathrm{SO}_{4}^{2-}$, and $\mathrm{NO}_{3}^{-}$ranging from 1 to $140 \mu \mathrm{g} \mathrm{m}^{-3}$. Additionally, Orsini et al. (2003) showed the collection efficiency of $\geq 95 \%$ for particles as small as $30 \mathrm{~nm}$ diameter for a $15 \mathrm{~L} \mathrm{~min}^{-1}$ sample flow rate. Ammonium $\left(\mathrm{NH}_{4}^{+}\right)$is the major ion susceptible to 


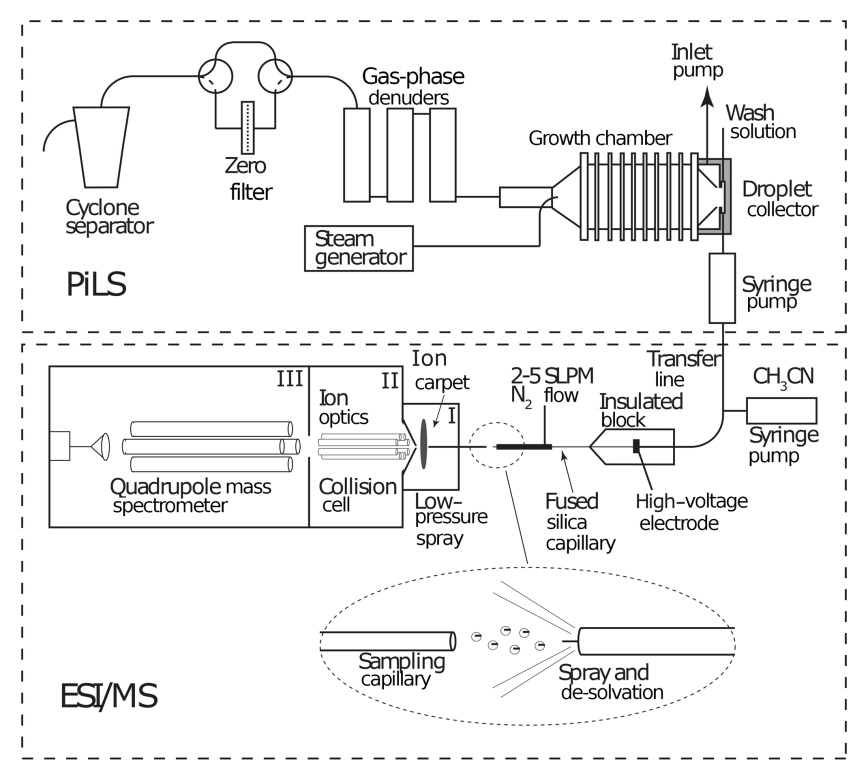

Figure 2. Schematic of a particle-into-liquid sampler (PILS; Sorooshian et al., 2006) interfaced to an electrospray ionization (ESI) source of a quadrupole mass spectrometer (MS) for continuous measurement of water-soluble components of atmospheric particles.

volatilization as shown in Ma (2004), who indicated an underestimation of $\sim 15 \%$. In this study, because we were operating in the negative-ion mode, we did not measure $\mathrm{NH}_{4}^{+}$ directly.

\subsection{Experimental design}

\subsubsection{Methods for determining gas-phase conversion efficiency}

The efficiency of conversion of several $\mathrm{N}$-containing gases by the $\mathrm{N}_{\mathrm{r}}$ catalyst was determined through addition of a number of representative compounds that were calibrated independently. The NO signal from the converted species was then compared to the signal from an $\mathrm{NO}$ in $\mathrm{N}_{2}$ standard (5.38 ppmv, Scott-Marrin Inc., Riverside, CA) that was used as the working standard for this project. Typical calibration levels were in the range of 50 to $100 \mathrm{ppbv}$ as determined by the mass flow controllers used to mix the standard into the measurement stream. The standards used for each compound and their associated calibrations were as follows.

The $\mathrm{NO}_{2}$ standard stream was produced from the NO working standard through gas-phase titration with a small stream of $\mathrm{O}_{2}$ in which $\mathrm{O}_{3}$ had been produced by photolysis at $184.9 \mathrm{~nm}$ using a mercury discharge lamp. This technique is used routinely for $\mathrm{NO}_{x}$ and $\mathrm{NO}_{y}$ measurement systems (Williams et al., 1998) and allows straightforward determination of $\mathrm{NO}_{2}$ conversion provided care is taken not to overtitrate the NO stream to produce $\mathrm{NO}_{3}$ and therefore $\mathrm{N}_{2} \mathrm{O}_{5}$. The uncertainty in the $\mathrm{NO}_{2}$ conversion determination is sim- ply the propagated errors in the subtraction of the signals before and after titration.

The ammonia $\left(\mathrm{NH}_{3}\right)$ conversion was examined using two different $\mathrm{NH}_{3}$ sources, a gas mixture (3.1 ppmv in $\mathrm{N}_{2}$, ScottMarrin), and a permeation device (Kin-Tek, La Marque, Texas). Care was taken with these standards to keep them under flow for periods of several days in order to insure any system surfaces were equilibrated. The calibration of these standards was accomplished with ultraviolet (UV) absorption spectroscopy at a $184.9 \mathrm{~nm}$ wavelength using an instrument described by Neuman et al. (2003), and based on absorption cross sections reported in the literature (Tannenbaum et al., 1953; Lovejoy, 1999; Froyd, 2002). The uncertainty of $\mathrm{NH}_{3}$ conversion was propagated based on the uncertainties in flow rate and UV absorption determinations.

The hydrogen cyanide (HCN) standard consisted of a commercial gravimetric mixture of $\mathrm{HCN}$ in $\mathrm{N}_{2}$ (10 ppmv, Gasco, Oldsmar, FL), which was mixed into the system using a mass flow controller. The specified uncertainty of this mixture was $\pm 10 \%$, and the standard concentration was verified using long-path Fourier-transform infrared (FTIR) spectroscopy to within the stated uncertainty. The HCN standard was used to produce a gas-phase stream of cyanogen chlorine $(\mathrm{ClCN})$ by reaction with chloramine- $\mathrm{T}$, a nonvolatile chlorinating agent, which has been described previously (Valentour et al., 1974). To do this, a small stream (5 standard $\left.\mathrm{cm}^{3} \mathrm{~min}^{-1}\right)$ of the HCN standard was combined with humidified ZA $(60 \%$ $\mathrm{RH}, 30$ standard $\mathrm{cm}^{3} \mathrm{~min}^{-1}$ ) over a bed packed with glass beads coated with a solution of chloramine-T. The glass beads were prepared by coating glass $3 \mathrm{~mm}$ outer diameter (OD) beads with a $2 \mathrm{~g} 100 \mathrm{~mL}^{-1}$ solution and packing $\sim 20 \mathrm{~cm}^{3}$ of them in a $12.7 \mathrm{~mm}$ OD PFA tube and flowing ZA over them until dry. The reaction was shown to be essentially $100 \%( \pm 10 \%)$ using proton-transfer-reaction mass spectrometry (PTR-MS), when conducted in a humidified atmosphere (RH $\geq 60 \%)$, and by FTIR analysis of the HCN and $\mathrm{ClCN}$ in the gas stream before and after chlorination.

The isocyanic acid (HNCO) standard was prepared according to the methods described by Roberts et al. (2010), in which the trimer, cyanuric acid, was thermally decomposed at $250^{\circ} \mathrm{C}$ in a diffusion cell to produce a steady stream of HNCO, which was then calibrated using long-path FTIR spectroscopy. Initially, this source has the potential to produce $\mathrm{NH}_{3}$ as an impurity, most likely because of the presence of trace amounts of water. Keeping the source under flow and above $120^{\circ} \mathrm{C}$ at all times when not in use was found to reduce the $\mathrm{NH}_{3}$ impurity to negligible levels $(<5 \%)$, as measured using PTR-MS. The uncertainties in the HNCO standard were propagated from the uncertainties in the HNCO cross section (Northwest Infrared, PNNL), the $\mathrm{NH}_{3}$ subtraction, and flow rates. Standard streams of both nitrobenzene and trimethylamine were produced using gravimetrically prepared solutions and a commercial liquid calibration device (Ionicon, Innsbruck, Austria). The uncertainties in these liquid calibration standards were estimated from the 
propagated uncertainties in the solution concentrations and the liquid and gas flow rates.

The conversion of nitrous oxide $\left(\mathrm{N}_{2} \mathrm{O}\right)$ is a potential interference in the $\mathrm{N}_{\mathrm{r}}$ method as $\mathrm{N}_{2} \mathrm{O}$ is not typically considered a reactive nitrogen compound in the troposphere. Several experiments were conducted to determine the extent of this potential interference using a $10.1 \mathrm{ppmv} \mathrm{N}_{2} \mathrm{O}$ standard. The resulting conversion efficiency ranged from 0.03 to $0.05 \%$ in dry and humidified air, respectively. These can be considered upper limits for this interference as we cannot be completely sure that there were no $\mathrm{N}_{\mathrm{r}}$ contaminants (e.g., $\mathrm{NO}_{2}$ ) in the $\mathrm{N}_{2} \mathrm{O}$ standard.

\subsubsection{Methods for determining particle-phase conversion efficiency}

Several aerosols were generated including polystyrene latex spheres (PSLs; Nanosphere size standards, Thermo Fisher Scientific Inc., Waltham, MA), $\mathrm{NH}_{4} \mathrm{NO}_{3},\left(\mathrm{NH}_{4}\right)_{2} \mathrm{SO}_{4}$, $\left(\mathrm{NH}_{4}\right)_{2} \mathrm{C}_{2} \mathrm{O}_{4}$ (Sigma Aldrich, St. Louis, MO), $\mathrm{NH}_{4} \mathrm{Cl}$ (J. T. Baker Chemical Co., Phillipsburg, NJ), and $\mathrm{NaNO}_{3}$ (Fisher Scientific, Hampton, NH). Aerosol particles were generated by atomizing aqueous solutions of pure compounds in distilled water $\left(\sim 0.5-6 \mathrm{~g} \mathrm{~L}^{-1}\right)$ using a custombuilt Collison-type atomizer (similar to one reported by Liu and Lee, 1975) in a dry particle-free nitrogen or ZA flow. The output flow was dried using a silica gel diffusion dryer to a relative humidity (RH) less than $10 \%$. The dry polydisperse particles were then size-selected using a custombuilt differential mobility analyzer (DMA; similar to one described by Knutson and Whitby, 1975). The DMA was operated at a sample flow of $0.3-0.5$ volumetric $\mathrm{L} \mathrm{min}^{-1}$ and a ratio of 10:1 between the sheath and sample flow. The particles were diluted with ultra-high-purity filtered ZA (range $1-10 \mathrm{~L} \mathrm{~min}^{-1}$ ) before entering a mixing vessel. In instances in which a mixing vessel was not available, a segment of smaller diameter tubing was added in-line to promote mixing prior to the flow being divided among the instruments. A condensation particle counter (CPC; 3022A, TSI Inc., Shoreview, MN) (Stolzenburg and McMurry, 1991) continuously measured the particle number concentration of the DMA output flow, following dilution. We measured the CPC flow rate pre- and post-sampling using a low-flow DryCal (Mesa Laboratories, Lakewood, $\mathrm{CO}$ ) and estimate an uncertainty in the CPC flow rate calibration to be $\pm 1 \%$. During several experiments, the aerosol flow was split and sampled by an ultra-high-sensitivity aerosol spectrometer (UHSAS; Droplet Measurement Technologies, Longmont, CO) to continuously measure the particle concentration and size distribution for particles with diameters between $\sim 63$ and $1000 \mathrm{~nm}$.

For the liquid concentrations, atomizer conditions, and DMA settings used here, the DMA output size distribution was a multi-peaked population consisting not only of singly charged particles but also particles with multiple (mostly two or three) charges that could contribute significantly to the overall particle mass. Hence the particle mass could not be calculated directly from the singly charged mobility diameter, particle density, and the CPC number concentrations. We generally used two methods to calculate the particle mass concentrations for these experiments. For the first method, the size distributions were measured using the scanning mobility particle sizer (SMPS; Wang and Flagan, 1990) function of the DMA (physical diameter, $D_{\mathrm{p}}=1-1000 \mathrm{~nm}$ ). We used the DMA transfer theory (Knutson and Whitby, 1975; Stolzenburg, 1988) with the steady-state charge distribution approximation of Wiedensohler (1988) to estimate the fraction of multiply charged particles contributing to the CPC number concentration for each diameter setting. There are a number of possible sources of uncertainty using these methods that may include particle losses, DMA transfer function uncertainty, counting uncertainty, and inversion errors. When comparing mass concentrations from the SMPS with those measured by the $\mathrm{N}_{\mathrm{r}}$ system, issues with the SMPSderived size distributions became apparent (discussed separately in Sect. 3.2.2). For the second method of calculating mass concentrations, we directly measured the diluted DMA output using the UHSAS. UHSAS particle sizing is a function of the amount of light scattered onto the photodetectors, which depends not only on the particle size but also on the composition-dependent particle refractive index (Bohren and Huffman, 1983; Liu and Daum, 2000; Hand and Kreidenweis, 2002; Rosenberg et al., 2012). The UHSAS manufacturer recommended calibration uses PSL microspheres, which are well characterized and have a known refractive index $(n=1.58)$ and shape. Because the UHSAS sizing is sensitive to particle refractive index, a new sizing calibration curve was produced for each studied particle type (i.e., refractive index) using a DMA to select particles for a range of known sizes (Kupc et al., 2018). These calibration curves were used to retrieve accurate particle size distributions that properly accounted for the multiply charged particles.

Differences in particle counting efficiency between the UHSAS and CPC are potentially important. Previous laboratory studies show UHSAS and CPC number concentration comparisons in excellent agreement (Cai et al., 2008; Kupc et al., 2018); however, occasionally only a $\sim 90 \%$ counting efficiency for the UHSAS was observed when compared to the CPC. These differences are attributed to particle coincidence at high concentrations $\left(>1000 \mathrm{~cm}^{-3}\right)$ and to inefficient particle mixing before reaching the instruments. Corrections for particle coincidence were applied (Kupc et al., 2018) though we expect differences due to particle mixing add an additional $10 \%$ uncertainty to the measurements. The UHSAS- and CPC-measured particle number concentrations were generally within $10 \%$ of each other; however, the CPC values did not require coincidence corrections and had a better signal-to-noise ratio. Due to problems with measuring SMPS size distributions and requiring coincidence corrections for the UHSAS number concentrations, we used the UHSAS size distributions with the total particle number 
taken from the CPC measurement to calculate particle mass from total volume and density.

\subsubsection{Nitrogen-containing particles}

The measurement of particle-phase $\mathrm{N}_{\mathrm{r}}$ requires decomposition or volatilization of the solid material, followed by catalytic conversion to $\mathrm{NO}$ (or $\mathrm{NO}_{2}$ ). Broadly, there are three types of $\mathrm{N}_{\mathrm{r}}$-containing particles, with a range of thermal stabilities from volatile to refractory. First, there is considerable literature that indicates that small particles composed of two major semi-volatile species, ammonium nitrate $\left(\mathrm{NH}_{4} \mathrm{NO}_{3}\right)$ and ammonium chloride $\left(\mathrm{NH}_{4} \mathrm{Cl}\right)$, will dissociate to constituents $\mathrm{NH}_{3}$ and $\mathrm{HNO}_{3}$ (and $\mathrm{HCl}$ ) when modestly heated to temperatures $<100^{\circ} \mathrm{C}$ (Huffman et al., 2009; $\mathrm{Hu}$ et al., 2011). These materials will be readily converted on high-temperature catalysts (e.g., platinum, Pt) as gas-phase $\mathrm{NH}_{3}$ and $\mathrm{HNO}_{3}$. The second type of $\mathrm{N}_{\mathrm{r}}$-containing particles include intermediate-stability compounds consisting mostly of nitro-organics $\left(\mathrm{R}-\mathrm{NO}_{2}\right)$, organic nitrates $\left(\mathrm{RONO}_{2}\right)$, and amine and ammonium salts of acids. These compounds begin to decompose at relatively low temperatures. For example, thermal decomposition studies of bulk ammonium oxalate $\left(\left(\mathrm{NH}_{4}\right)_{2} \mathrm{C}_{2} \mathrm{O}_{4}\right)$ indicate that it begins to decompose at temperatures slightly above $200^{\circ} \mathrm{C}$ (Usherenko et al., 1988). Similarly, bulk samples of ammonium sulfate $\left(\left(\mathrm{NH}_{4}\right)_{2} \mathrm{SO}_{4}\right)$ and ammonium bisulfate $\left(\left(\mathrm{NH}_{4}\right) \mathrm{HSO}_{4}\right)$ decompose at approximately $150-250^{\circ} \mathrm{C}$ depending on water content (Kiyoura and Urano, 1970). Given sufficient residence time, intermediate-volatility compounds will start to convert to gas-phase products in the hot inlet tubing and fully convert to $\mathrm{NO}$ (or $\left.\mathrm{NO}_{2}\right)$ on a hot Pt surface $\left(750^{\circ} \mathrm{C}\right)$. The third type of $\mathrm{N}_{\mathrm{r}}$-containing particles are composed of refractory salts such as sodium nitrate $\left(\mathrm{NaNO}_{3}\right)$, which will be the most resistant to decomposition and require contact with high-temperature surfaces of the Pt catalyst. Studies of the thermal decomposition of $\mathrm{NaNO}_{3}$ on Pt surfaces indicate that $\mathrm{NO}$ is evolved starting at about $500{ }^{\circ} \mathrm{C}$. In summary, the existing literature suggests that the thermal decomposition and conversion of $\mathrm{N}_{\mathrm{r}}$-containing particles to $\mathrm{NO}\left(\mathrm{NO}_{2}\right)$ is thermodynamically feasible provided there is sufficient residence time and surface area in the catalyst zone.

\section{Instrument characterization}

\section{1 $\mathrm{N}_{\mathrm{r}}$ gas-phase conversion efficiency}

We verified the efficiency of conversion of a range of gasphase $\mathrm{N}_{\mathrm{r}}$ compounds in this catalyst system using calibrated gas mixtures or standard streams and auxiliary analysis methods as described in Sect. 2.2.1. The conversion efficiencies are summarized in Table 1 and range from 95 to $110 \%$. The values were based on the ratios of the $\mathrm{N}_{\mathrm{r}}$ measured as NO to the expected values specified by each calibration method. The uncertainties in the measured conversion efficiencies are in the propagated errors in each calibration method, and in all cases the range encompasses $100 \%$ conversion. For example, the largest uncertainty in the $\mathrm{NH}_{3}$ conversion efficiency was the $\mathrm{NH}_{3} \mathrm{UV}$ absorption cross section at $184.9 \mathrm{~nm}$ (value of $4.4 \pm 0.3 \times 10^{-18} \mathrm{~cm}^{2}$ taken from Neuman et al., 2003). It is possible that there were $\mathrm{N}_{\mathrm{r}}$ compounds in the standard stream aside from $\mathrm{NH}_{3}$ that were responsible for the result being $>100 \%$. However, the fact that the determination was above $100 \%$ for both a permeation source and a gas-phase mixture (3.1 ppmv in $\mathrm{N}_{2}$ ) implies that the UV absorption cross section is high by $5-10 \%$ or that there were contaminants in both calibration sources. $\mathrm{NH}_{3}$ is one of the more important reactive nitrogen species in the atmosphere-biosphere system and is thermodynamically one of the more difficult to convert. Compounds considered $\mathrm{NO}_{y}$ species, such as nitric acid, acetyl peroxynitrates, and alkyl nitrates, were not studied in this work (aside from $\mathrm{NO}_{2}$ ) since they are known to be converted at high efficiency on precious metal (Fahey et al., 1986) or molybdenum oxide (Winer et al., 1974) catalysts. The resulting uncertainties in the $\mathrm{N}_{\mathrm{r}}$ measurement are estimated to be $\pm 10 \%$ based on comparisons of measured NO signals to individual $\mathrm{N}_{\mathrm{r}}$ compound calibrations.

$\mathrm{N}_{2} \mathrm{O}$ is a potential interference that is discussed in Sect. 2.2.1, though in this instance the conversion efficiency upper limit determined for this instrument is a negligible interference in the $\mathrm{N}_{\mathrm{r}}$ measurements in ambient air or ZA matrices, and likewise will not be significant in biomass burning sources given that $\mathrm{N}_{2} \mathrm{O}$ enhancements in fresh biomass smoke are generally not observed or contribute minimally to total nitrogen (Griffith et al., 1991). $\mathrm{N}_{2} \mathrm{O}$ emissions from other sources (e.g., natural and anthropogenic agricultural sources, fossil fuel combustion, or animal waste) can be significant; therefore the interference from $\mathrm{N}_{2} \mathrm{O}$ conversion must be considered. $\mathrm{O}_{3}$ is another potential source of gasphase interference due to the decomposition of $\mathrm{O}_{3}$ to $\mathrm{O}_{2}+\mathrm{O}$, followed by reaction of $\mathrm{O}$ with $\mathrm{N}_{2} \mathrm{O}$ at high temperature to form NO. However, the NO production in the $\mathrm{O}+\mathrm{N}_{2} \mathrm{O}$ reaction is an approximately $20 \%$ channel with a net rate constant of approximately $1 \times 10^{-15} \mathrm{~cm}^{3}$ molecule ${ }^{-1} \mathrm{~s}^{-1}$ at $750{ }^{\circ} \mathrm{C}$ (NIST, 2017). If all the $\mathrm{O}$ atoms from 70 ppbv of $\mathrm{O}_{3}$ were available for reaction with an ambient level of $\mathrm{N}_{2} \mathrm{O}$ ( $340 \mathrm{ppbv}$ ), then the $0.1 \mathrm{~s}$ residence time in the converter would result in approximately 28 pptv of NO, an upper limit that is generally a negligible amount in almost any atmospheric context except in remote regions.

\section{2 $\mathrm{N}_{\mathrm{r}}$ particle measurements}

\subsection{1 $\mathrm{N}_{\mathrm{r}}$ system setup and response}

The atomizer output was diluted with particle-free nitrogen and ultrapure ZA; therefore, the $\mathrm{N}_{\mathrm{r}}$ measurement should theoretically be attributed to particles only since no detectable gas-phase nitrogen is added to the sample stream. However, equilibration within the sample lines may result in out- 
Table 1. Conversion efficiencies of $\mathrm{N}_{\mathrm{r}}$ compounds by the Pt and MoOx catalyst system.

\begin{tabular}{llll}
\hline Compound & $\begin{array}{l}\text { Conversion } \\
\text { efficiency (\%) }\end{array}$ & Calibration method & Reference \\
\hline Nitrogen dioxide, $\mathrm{NO}_{2}$ & $99 \pm 2$ & Titration of NO standard by $\mathrm{O}_{3}$ & Williams et al. (1998) \\
Ammonia, $\mathrm{NH}_{3}$ & $105-110 \pm 15$ & Permeation tube or gas mixture, UV absorbance at 184.9 nm & Neuman et al. (2003) \\
Hydrogen cyanide, $\mathrm{HCN}$ & $101-102 \pm 10$ & Gravimetric gas mixture & Gasco, Oldsmar, FL. \\
Cyanogen chloride, $\mathrm{ClCN}$ & $98 \pm 10$ & Conversion of HCN standard with Chloramine- $\mathrm{T}$ & Valentour et al. (1974) \\
Isocyanic acid, $\mathrm{HNCO}$ & $100 \pm 25$ & Decomposition of the trimer, FTIR & Roberts et al. (2010) \\
Nitrobenzene, $\mathrm{C}_{6} \mathrm{H}_{5} \mathrm{NO}_{2}$ & $95 \pm 15$ & Liquid calibration unit, liquid flow, and gravimetric concentration & Ionicon, Innsbruck, Austria \\
Triethyl amine, $\left(\mathrm{C}_{2} \mathrm{H}_{5}\right)_{3} \mathrm{~N}$ & $95 \pm 15$ & Liquid calibration unit, liquid flow, and gravimetric concentration & Ionicon, Innsbruck, Austria \\
\hline
\end{tabular}
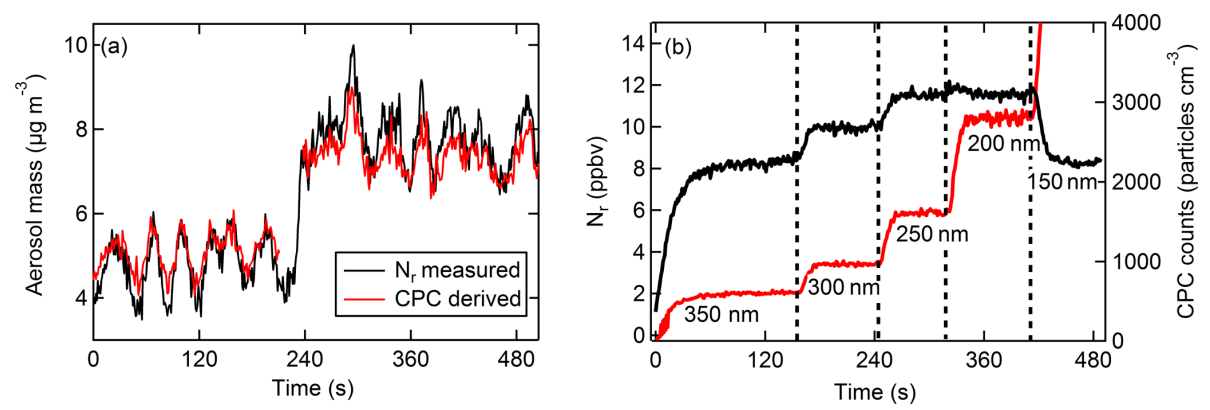

Figure 3. The signal resulting from particles only. (a) Real-time $\mathrm{N}_{\mathrm{r}}$-measured (black) and CPC-derived (red) aerosol mass concentrations $\left(\mu \mathrm{g} \mathrm{m}^{-3}\right.$ ) from an atomized solution of $\mathrm{NaNO}_{3}$. (b) Time response of the $\mathrm{N}_{\mathrm{r}}$ signal (ppbv) shown in black (left axis), and the CPC signal (particles $\mathrm{cm}^{-3}$ ) shown in red (right axis), as particle sizes of $\left(\mathrm{NH}_{4}\right)_{2} \mathrm{SO}_{4}$ are selectively changed. The dashed vertical lines and labels indicate the singly charged particle diameter selected with the DMA.

gassing and formation of gas-phase compounds affecting total $\mathrm{N}_{\mathrm{r}}$ detection. Figure $3 \mathrm{a}$ shows the initial response of the $\mathrm{N}_{\mathrm{r}}$ system in cleaned inlets for $\mathrm{NaNO}_{3}$. The $\mathrm{N}_{\mathrm{r}}$ mass signal tracks the CPC-derived aerosol mass features closely as the aerosol source concentrations fluctuate. Additionally, as different particle sizes are selected by the DMA for $\left(\mathrm{NH}_{4}\right)_{2} \mathrm{SO}_{4}$ (Fig. 3b), changes in the total $\mathrm{N}_{\mathrm{r}}$ response are fast and precisely track the changes in the CPC signal. The potential gasphase constituents equilibrating in the lines from aerosols in this study include $\mathrm{HNO}_{3}, \mathrm{HCl}$, and $\mathrm{NH}_{3}$. If these compounds formed before reaching the $\mathrm{N}_{\mathrm{r}}$ catalyst it is likely adsorption and desorption from inlets and tubing surfaces would occur (e.g., Neuman et al., 1999; Yokelson et al., 2003). As an example, the presence of $\mathrm{NH}_{3}$ in Fig. $3 \mathrm{~b}$ (or $\mathrm{HNO}_{3}$ in nitrate-containing particles) would be indicated by a delayed and lengthened rise or fall in the $\mathrm{N}_{\mathrm{r}}$ response with sudden changes to the input concentrations. However, the total $\mathrm{N}_{\mathrm{r}}$ response precisely tracks the CPC signal on rapid timescales (a few seconds), suggesting that gas-phase $\mathrm{NH}_{3}$ was not present in significant quantities. In experiments at exceptionally high aerosol loadings of $\left(\mathrm{NH}_{4}\right)_{2} \mathrm{C}_{2} \mathrm{O}_{4}$ (up to several parts per million volume of total $\mathrm{N}_{\mathrm{r}}$, i.e., several thousand micrograms per cubic meter) $\mathrm{N}_{\mathrm{r}}$ signal "tailing" was observed, suggesting that $\mathrm{NH}_{3}$ was scavenging to the walls of the inlet before the heated quartz tubing.

Marx et al. (2012) reported calculated conversion efficiencies in air sampled from a small chamber for $\mathrm{NaNO}_{3}$,
$\mathrm{NH}_{4} \mathrm{NO}_{3}$, and $\left(\mathrm{NH}_{4}\right)_{2} \mathrm{SO}_{4}$ to be 78,142 , and $91 \%$, respectively. The authors suggested the overestimation of $\mathrm{NH}_{4} \mathrm{NO}_{3}$ was a result of its semi-volatile properties under ambient conditions that led to the formation of gaseous $\mathrm{NH}_{3}$ and $\mathrm{HNO}_{3}$ in the chamber. For these reasons, we limit the background artifacts and volatilization effects that may have occurred during chamber filling and sampling in Marx et al. (2012) by sampling immediately following solution atomization through conductive tubing at relatively high sample flow rates. Additionally, we use a DMA to size-select the atomized polydisperse aerosol to evaluate the particle conversion efficiency at several different diameters $(100-600 \mathrm{~nm}$ in $50 \mathrm{~nm}$ increments) to investigate the volatilization effects and conversion efficiencies of smaller particles for the extended list of $\mathrm{N}_{\mathrm{r}^{-}}$ containing aerosols studied in our work.

\subsubsection{Challenges using the DMA/SMPS to determine $\mathrm{N}_{\mathrm{r}}$-particle conversion efficiency}

The voltage scanning (SMPS) function of the DMA and number concentration measurements by the CPC are a conventional method to determine particle size distributions, and for calculating particle mass from total volume and density, assuming spherical particles. For the total nitrogen measurements, the total particle-bound $\mathrm{N}_{\mathrm{r}}$ mixing ratios were retrieved and converted to mass concentrations for each corresponding salt. Figure $4 \mathrm{a}-\mathrm{d}$ show the SMPS-calculated vs. 

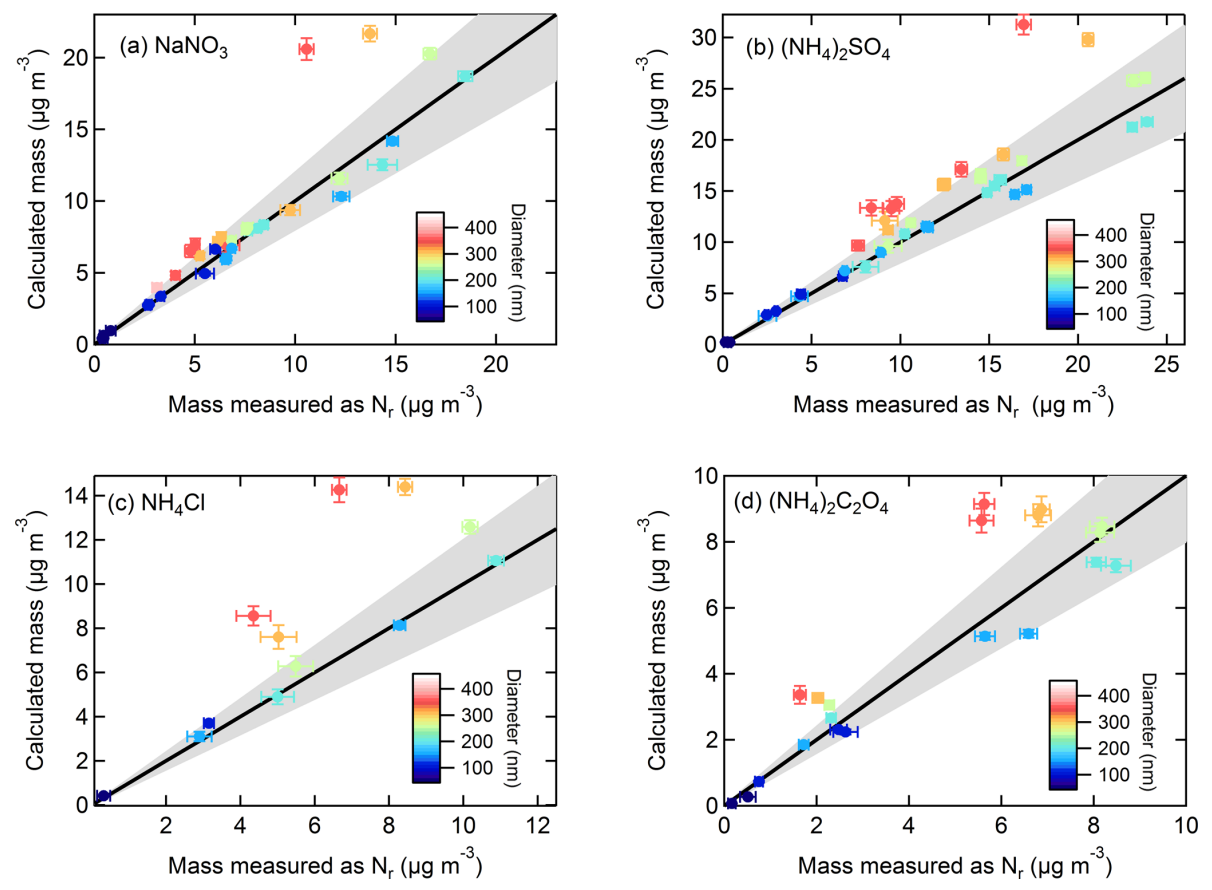

Figure 4. Calculated mass from particles size-selected by the DMA and corrected for multiply charged particles using SMPS-derived size distributions compared to aerosol mass concentrations $\left(\mu \mathrm{g} \mathrm{m}^{-3}\right)$ measured as $\mathrm{N}_{\mathrm{r}}$ for (a) $\mathrm{NaNO}_{3},(\mathbf{b})\left(\mathrm{NH}_{4}\right)_{2} \mathrm{SO}_{4},(\mathbf{c}) \mathrm{NH}_{4} \mathrm{Cl}$, and (d) $\left(\mathrm{NH}_{4}\right)_{2} \mathrm{C}_{2} \mathrm{O}_{4}$. The particle size is designated by the color plot (error bars indicate $\pm 1 \mathrm{SD}$ ) and the 1:1 line is shown in black with $20 \%$ error indicated by the grey shading.

$\mathrm{N}_{\mathrm{r}}$-measured mass concentrations $\left(\mu \mathrm{g} \mathrm{m}^{-3}\right.$ ) for particles of different composition and diameter. The plots show that a strong correlation $\left(R^{2}>0.98\right)$ and good agreement was obtained for smaller particles $(50-200 \mathrm{~nm})$ with slopes ranging from 0.86 to 0.97 , while for larger particles $(\geq 250 \mathrm{~nm})$ the mass-calculated values from the SMPS-derived distributions were sometimes as much as $>50 \%$ too high. The $R^{2}$ for all particles including $\geq 250 \mathrm{~nm}$ ranged from 0.71 to 0.85 with slopes of 1.08-1.36.

For larger particles, we used a UHSAS to determine the size distribution of multiply charged species exiting the DMA. The SMPS inversion-derived size distributions were generally broader than the UHSAS size distributions, though agreement improved at increased scan times. Small differences in the size distribution recovered from the voltage scans at larger diameters $(>200 \mathrm{~nm})$ affected the mass distribution considerably because particle mass scales with diameter cubed. A possible explanation is that we are not correctly accounting for the delay time from the DMA exit to the CPC; therefore the particle counts did not correspond to the correct size designated from voltage scanning and this likely skewed the size distribution relative to the true distribution (Collins et al., 2002). Methods for limiting these effects exist (Russell et al., 1995; Collins et al., 2002), including slower voltage scan rates. However, our results demonstrate the added challenges in particle mass determination using estimated size distributions from the SMPS method. For the remaining discussion, we measure the size distributions directly using the UHSAS with particle concentration measurements (by either the CPC or UHSAS) to evaluate the $\mathrm{N}_{\mathrm{r}}$ particle conversion in the $\mathrm{N}_{\mathrm{r}}$ system.

\subsubsection{Determining $\mathrm{N}_{\mathrm{r}}$-particle conversion efficiency using a DMA and UHSAS}

For the aerosol mass concentrations $\left(\mu \mathrm{g} \mathrm{m}^{-3}\right)$ calculated using UHSAS particle size distributions, we refer to these values as UHSAS-calculated mass. Comparisons of the mass directly measured as $\mathrm{N}_{\mathrm{r}}$ versus UHSAS-calculated mass concentrations for atomized solutions of $\mathrm{NaNO}_{3},\left(\mathrm{NH}_{4}\right)_{2} \mathrm{SO}_{4}$, $\mathrm{NH}_{4} \mathrm{Cl}$, and $\left(\mathrm{NH}_{4}\right)_{2} \mathrm{C}_{2} \mathrm{O}_{4}$ are shown in Fig. 5 with orthogonal distance regression lines with slopes that range from 0.910 to 1.06 for concentrations from $\sim 0$ to $70 \mu \mathrm{g} \mathrm{m}^{-3}$. The instruments are highly correlated $\left(R^{2}=0.90-0.99\right)$ and the fits indicate that for the salts tested there is quantitative conversion of particulate nitrogen, to within the combined uncertainties of the methods, independent of diameter (range: 100-600 nm). More detailed particle conversion efficiencies by size are shown in Table 2 for each aerosol tested. On average across all size ranges the results indicate $97 \pm 7$, $101 \pm 5,100 \pm 10$, and $93 \pm 5 \%$ particle conversion efficiencies for $\mathrm{NaNO}_{3},\left(\mathrm{NH}_{4}\right)_{2} \mathrm{SO}_{4}, \mathrm{NH}_{4} \mathrm{Cl}$, and $\left(\mathrm{NH}_{4}\right)_{2} \mathrm{C}_{2} \mathrm{O}_{4}$, respectively. The largest deviation from the one-to-one line occurred for $\left(\mathrm{NH}_{4}\right)_{2} \mathrm{C}_{2} \mathrm{O}_{4}$, which may imply some ammonia 

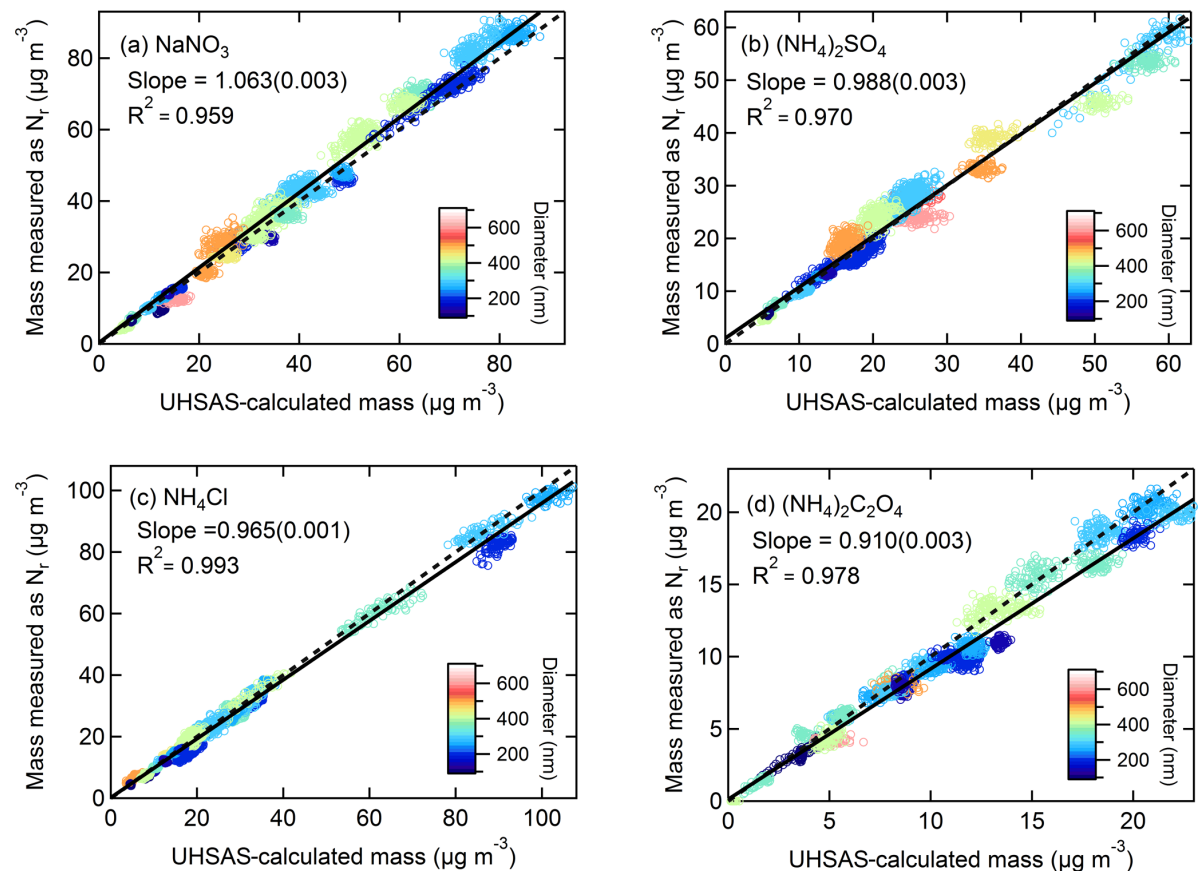

Figure 5. Correlation plots of mass concentrations measured as $\mathrm{N}_{\mathrm{r}}$ for (a) $\mathrm{NaNO}_{3}$, (b) $\left(\mathrm{NH}_{4}\right)_{2} \mathrm{SO}_{4}$, (c) $\mathrm{NH}_{4} \mathrm{Cl}$, and (d) $\left(\mathrm{NH}_{4}\right) \mathrm{C}_{2} \mathrm{O}_{4}$ versus mass concentrations calculated using CPC number concentrations with UHSAS size distributions. Particle sizes (nm) are indicated by the color plot and the 1:1 line is shown in dashed black. The solid lines are orthogonal distance regression fits. The slope (uncertainty) and $R^{2}$ is shown.

loss, though the agreement is generally still within $10 \%$ for most particle sizes.

For the case of $\mathrm{NH}_{4} \mathrm{NO}_{3}$, the UHSAS-measured size distribution peaked at significantly lower diameters than expected based on the DMA size selection. This difference has been reported previously (Cai et al., 2008; Womack et al., 2017), though to a lesser extent $(\sim 8 \%)$ than observed here (up to $30 \%$ ). Possible explanations for these differences could include vaporization and/or evaporation effects, residual water in the particles, surface effects, or differences in electrical mobility diameter and geometric diameter due to non-sphericity as discussed in DeCarlo et al. (2004). For these reasons, we made no attempt to characterize $\mathrm{NH}_{4} \mathrm{NO}_{3}$ behavior in either the DMA or UHSAS and refer to Sect. 4 for mass concentration comparisons of polydisperse aerosol measured using separate mass measurement techniques (both the $\mathrm{N}_{\mathrm{r}}$ system and PILS-ESI/MS). It is worth noting that $\mathrm{NH}_{4} \mathrm{NO}_{3}$ is one of the more volatile compounds included in this study and it is reasonable to expect similar particle conversion efficiencies in the $\mathrm{N}_{\mathrm{r}}$ system catalysts for $\mathrm{NH}_{4} \mathrm{NO}_{3}$ as the other species tested (Table 2).

\subsection{Carbon conversion efficiency of Pt catalyst}

The high-temperature platinum catalyst should quantitatively convert carbon-containing species to $\mathrm{CO}_{2}$ in the presence of air. Therefore, the addition of a $\mathrm{CO}_{2}$ analyzer to the system as described in Sect. 2.1.2 allows for simultane-
Table 2. Particle conversion efficiencies (\%) with uncertainties (1 standard deviation) in parentheses. The sizing accuracy is $\sim \pm 2.5 \%$ using NIST-traceable PSLs for $150-500 \mathrm{~nm}$ spheres as our calibration standard.

\begin{tabular}{lrrrr}
\hline $\begin{array}{l}\text { Diameter } \\
(\mathrm{nm})\end{array}$ & $\mathrm{NaNO}_{3}$ & $\left(\mathrm{NH}_{4}\right)_{2} \mathrm{SO}_{4}$ & $\mathrm{NH}_{4} \mathrm{Cl}$ & $\left(\mathrm{NH}_{4}\right)_{2} \mathrm{C}_{2} \mathrm{O}_{4}$ \\
\hline 100 & $88.4(18.3)$ & $100.6(3.0)$ & $89.2(5.9)$ & $91.0(3.5)$ \\
150 & $94.0(10.9)$ & $96.5(2.5)$ & $93.4(4.7)$ & $89.0(6.6)$ \\
200 & $98.6(4.0)$ & $98.8(4.8)$ & $93.6(4.2)$ & $90.2(5.1)$ \\
250 & $101(3)$ & $100(3)$ & $98.3(3.7)$ & $94.7(5.6)$ \\
300 & $104(6)$ & $102(9)$ & $101(3)$ & $97.0(6.2)$ \\
350 & $102(6)$ & $101(9)$ & $98.5(5.2)$ & $101(13)$ \\
400 & $103(8)$ & $100(8)$ & $100(6)$ & $94.7(7.4)$ \\
450 & $95.1(4.5)$ & $110(4)$ & $103(6)$ & - \\
500 & $103(15)$ & $109(17)$ & $124(11)$ & $96.3(7.6)$ \\
600 & $83.2(8.7)$ & $91.9(5.5)$ & - & $82.5(8.4)$ \\
Average & $97.3(7.1)$ & $101(5)$ & $100(10)$ & $92.9(5.4)$ \\
\hline
\end{tabular}

ous measurements of $\mathrm{N}_{\mathrm{r}}$ and $\mathrm{C}_{y}$. Gas-phase carbon conversion across similar precious metals has been studied previously (e.g., Veres et al., 2010). The efficient conversion of gas-phase $\mathrm{C}$ compounds in our catalyst system was confirmed using a $\mathrm{CO}$ standard in air, and a combination $\mathrm{CO}_{2}$, $\mathrm{CO}$, and $\mathrm{CH}_{4}$ standards in air. The following discussion focuses on the conversion of particle-phase organic compounds (OC). The efficient conversion of $\mathrm{N}_{\mathrm{r}}$-containing particles was demonstrated in Sect. 3.2.2 for the range of $\mathrm{N}$ oxida- 


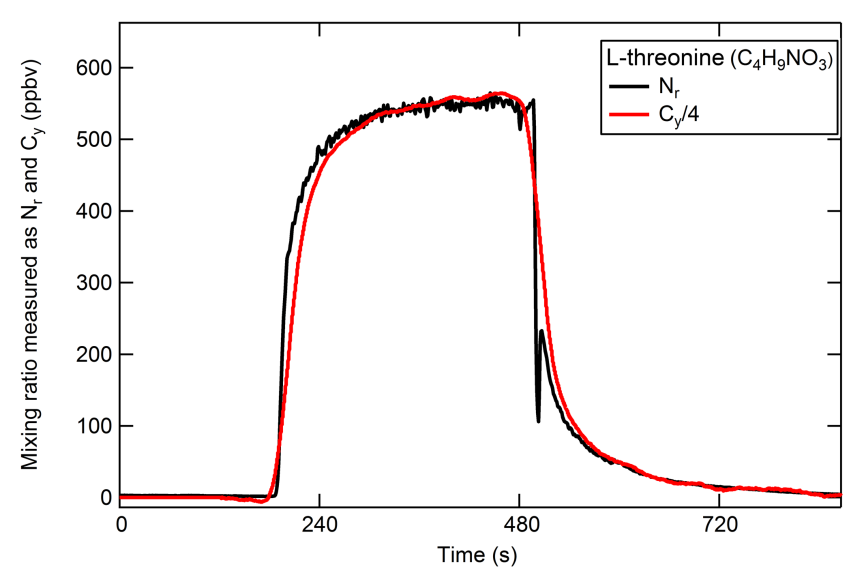

Figure 6. An example of the quantitative conversion of atomized polydisperse threonine $\left(\mathrm{C}_{4} \mathrm{H}_{9} \mathrm{NO}_{3}\right)$ to $\mathrm{NO}$ and $\mathrm{CO}_{2}$ measured using $\mathrm{NO}-\mathrm{O}_{3}$ chemiluminescence and a LI-COR-6251, respectively. The measured total $\mathrm{C}_{y}$ (red) is divided by the number of $\mathrm{C}$ atoms in threonine (four).

tion states and should extend to other $\mathrm{N}_{\mathrm{r}}$-containing particles; we expect that the resulting $\mathrm{N}_{\mathrm{r}}$ and $\mathrm{C}_{y}$ signals from each detector will be in proportion by dividing the result by the number of carbon and nitrogen atoms in the parent molecule to give the standard concentration on a molar basis. Polydisperse particulate OC was generated from the solution following an $\mathrm{N}_{2}$ purge to eliminate carbonate from the solution. Aerosol particles from solutions of anthranilic acid $\left(\mathrm{C}_{7} \mathrm{H}_{7} \mathrm{NO}_{2}\right.$, 2-aminobenzoic acid, Sigma Aldrich), threonine $\left(\mathrm{C}_{4} \mathrm{H}_{9} \mathrm{NO}_{3}\right.$, 2-amino-3-hydroxybutanoic acid, Sigma Aldrich), tryptophan $\left(\mathrm{C}_{11} \mathrm{H}_{12} \mathrm{~N}_{2} \mathrm{O}_{2}\right.$, 2-amino3-indolylpropanoic acid, Sigma Aldrich), and quinine $\left(\mathrm{C}_{20} \mathrm{H}_{24} \mathrm{~N}_{2} \mathrm{O}_{2}\right.$, Sigma Aldrich) were tested. These compounds were chosen based on their water solubility to avoid the use of organic solvents. An example of the $\mathrm{N}_{\mathrm{r}}$ and $\mathrm{C}_{y}$ response is shown in Fig. 6 for threonine (see Fig. S1 in the Supplement for additional compounds). The relative difference between the $\mathrm{N}_{\mathrm{r}}$ and $\mathrm{C}_{y}$ measured concentrations (up to several hundred parts per billion volume) is less than $10 \%$, which is within the propagated uncertainties of the $\mathrm{CO}_{2}$ calibration standards and both detection methods. We conclude that the $\mathrm{N}_{\mathrm{r}}$ catalyst with a $\mathrm{CO}_{2}$ detector in parallel can be used as a total carbon measurement system and would be useful to establish instrument calibrations for carbon-containing aerosol. The system is currently limited to calibration of compounds in ZA matrices because ambient levels of the common gas-phase carbon compounds $\mathrm{CO}_{2}, \mathrm{CO}$, and $\mathrm{CH}_{4}$ are high.

\section{4 $\mathrm{N}_{\mathrm{r}}$ measurements of biomass burning emissions}

As an example of both gas and particle measurements using the $\mathrm{N}_{\mathrm{r}}$ system, we follow with a brief discussion of $\mathrm{N}$ emissions from biomass burning. The primary gaseous $\mathrm{N}$ compounds in biomass burning plumes include $\mathrm{NO}, \mathrm{NO}_{2}$, $\mathrm{N}_{2}, \mathrm{NH}_{3}$, and to a lesser extent $\mathrm{HCN}, \mathrm{CH}_{3} \mathrm{CN}, \mathrm{HONO}$, HNCO (Lobert et al., 1990, 1991; Kuhlbusch et al., 1991; McMeeking et al., 2009; Burling et al., 2010; Stockwell et al., 2014, 2015), and other $\mathrm{N}_{\mathrm{r}}$-containing gases. Figure 7 shows results obtained from a representative fire (Fire 047) from the Fire Influence on Regional and Global environments Experiment (FIREX) 2016 Missoula Fire Lab study (https: //www.esrl.noaa.gov/csd/projects/firex/, last access: 6 May 2018). Figure 7a shows the co-measured $\mathrm{N}_{\mathrm{r}}$ and NO concentrations (ppmv). The majority of the $\mathrm{N}_{\mathrm{r}}$ system's response is due to the sum of gas-phase $\mathrm{N}_{\mathrm{r}}$ constituents that were measured by a FTIR spectrometer (Selimovic et al., 2018), an $\mathrm{H}_{3} \mathrm{O}^{+}$chemical ionization mass spectrometer (Koss et al., 2018), and a broadband cavity-enhanced extinction spectrometer (Min et al., 2016) (Fig. 7b). At the beginning of the burn (before 10:23 MST) the average relative percent difference between the total nitrogen signal and the sum of individually measured gas-phase compounds is $\sim 16 \%$, which is less than the combined error of the individual measurements. There is greater disagreement shown in Fig. 7c (difference is up to $\sim 1 \mathrm{ppmv}$; up to $\sim 50 \%$ relative percent difference) during other stages of the fire. The modified combustion efficiency (MCE) is a measure to estimate the relative contribution of flaming and smoldering combustion that occurred over the course of a fire, where the MCE is defined as the ratio of $\Delta \mathrm{CO}_{2} /\left(\Delta \mathrm{CO}_{2}+\Delta \mathrm{CO}\right)$ (Yokelson et al., 1996). $\mathrm{A}$ higher MCE value (approaching 0.99) designates relatively pure flaming combustion (more complete oxidation), and a lower MCE $(\sim 0.75-0.84)$ designates more smoldering combustion. We have shown in our laboratory experiments that there is quantitative $\mathrm{N}_{\mathrm{r}}$ particle conversion across the $\mathrm{N}_{\mathrm{r}}$ catalyst; therefore, it is possible that the residual signals are due to particulate N-containing compounds. Particulate ammonium may contribute to the excess $\mathrm{N}_{\mathrm{r}}$ signal measured during periods dominated by smoldering combustion $(\mathrm{MCE}<0.90)$. The oxidized $\mathrm{N}$-containing gas-phase species are relatively more abundant during the initial part of the fire; thus particulate nitrate could account for some $\mathrm{N}_{\mathrm{r}}$ signal during the flaming-dominated stages as shown in Fig. 7. By confirming particulate $\mathrm{N}_{\mathrm{r}}$ conversion in this system, it is possible that a total $\mathrm{N}$ budget can be reconstructed for additional laboratory fires measured during the FIREX laboratory study where individual particle-phase $\mathrm{N}_{\mathrm{r}}$ data are available.

\section{Application to calibrate the PILS-ESI/MS}

Here we demonstrate the capability of the total nitrogen system as an independent calibration method for other aerosol measurement systems. $\mathrm{N}_{\mathrm{r}}$ measurements of laboratorygenerated single-component inorganic and organic aerosol particles were used to characterize the PILS-ESI/MS. The strength of using the $\mathrm{N}_{\mathrm{r}}$ system to calibrate the PILS-ESI/MS and other aerosol mass instruments is that it is a direct 

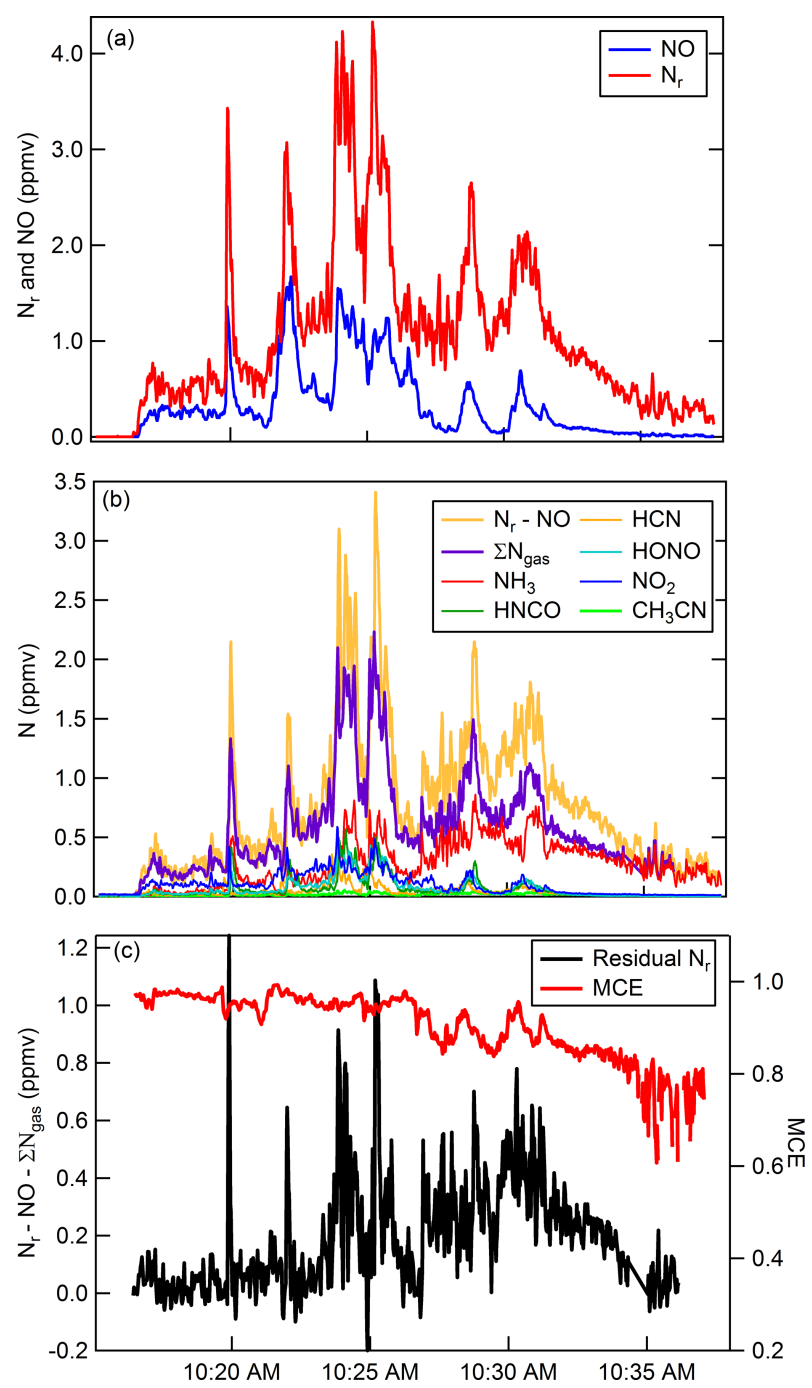

Figure 7. Time series for Fire Sciences Lab 2016 measurements of emissions from a subalpine fir canopy sample (Fire 047). (a) Total reactive nitrogen $\left(\mathrm{N}_{\mathrm{r}}\right.$, red) and nitric oxide (NO, blue) measurements. (b) Comparison of the difference $\left(\mathrm{N}_{\mathrm{r}}-\mathrm{NO}\right.$, gold) with the sum of the measured gas-phase $\mathrm{N}_{\mathrm{r}}$ species (purple). The sum of individually measured gas-phase species in order of abundance include $\mathrm{NH}_{3}, \mathrm{HNCO}, \mathrm{HCN}, \mathrm{HONO}, \mathrm{NO}_{2}, \mathrm{CH}_{3} \mathrm{NO}_{2}$, and 40 minor organic nitrogen species. $\mathrm{NO}_{2}$ and $\mathrm{HONO}$ were measured with a broadband cavity-enhanced extinction spectrometer, $\mathrm{HCN}$ and $\mathrm{NH}_{3}$ were measured with a FTIR spectrometer, and all remaining organic species were measured with a $\mathrm{H}_{3} \mathrm{O}^{+}$CIMS. (c) Residual $\mathrm{N}_{\mathrm{r}}$ (black) in parts per million volume with modified combustion efficiency overlaid (MCE, red).

method to calibrate the entire coupled online system. The current calibration approach for nearly all detectors used with the PILS involves liquid-phase standards to calibrate the detection method independently from the PILS.

The inorganic salts selected for the comparison between the $\mathrm{N}_{\mathrm{r}}$ and the PILS-ESI/MS instruments all contained $\mathrm{N}$ atoms, either in the cation, anion, or both. The total $\mathrm{N}_{\mathrm{r}}$ mea- sured as NO (ppbv) included all the $\mathrm{N}$ atoms atomized from the single-component solution. Dividing the total $\mathrm{N}_{\mathrm{r}}$ measurement by the number of $\mathrm{N}$ atoms in the parent molecule gives the standard concentration (ppbv) of the corresponding anion (e.g., $\mathrm{Cl}^{-}, \mathrm{NO}_{3}^{-}, \mathrm{SO}_{4}^{2-}, \mathrm{C}_{2} \mathrm{O}_{4}^{2-}$ ). The mixing ratios (ppbv) are converted to micrograms per cubic meter from the molecular weight of the corresponding anion. We refer to these mass concentrations as " $X$ measured as equivalent $\mathrm{N}_{\mathrm{r}}$ " in the remainder of the text, where $X$ is the corresponding anion of the aerosol particle. The anion mass calculated in this way was only necessary when comparing directly to PILS-ESI/MS measurements of ammonium salts of nitrate, sulfate, chloride, and oxalate.

\section{$\mathrm{N}_{\mathrm{r}}$ and PILS-ESI/MS mass concentration comparisons}

To compare to the calibration approaches using liquid-phase standards described in Sect. 2.1.3 for the PILS-ESI/MS, we performed particle mass comparisons using these methods with anion-specific mass concentrations derived from the $\mathrm{N}_{\mathrm{r}}$ measurement system. A single-component aerosol was used to minimize complex matrix effects including ion suppression and enhancement common in ESI.

An example of the $\mathrm{N}_{\mathrm{r}}$ system and PILS-ESI/MS cosampling a laboratory-generated polydisperse aerosol stream is shown in Fig. 8. Here we did not size-select aerosols but measured all particle sizes below a $2.5 \mu \mathrm{m}$ cutoff (URG cyclone, Chapel Hill, NC). There are two reasons for this experimental setup: (1) generating a sufficient aerosol mass concentration to calibrate the PILS-ES/MS was challenging because it requires a minimum flow of $11 \mathrm{~L} \mathrm{~min}^{-1}$, while the DMA output flow is $<1 \mathrm{~L} \mathrm{~min}^{-1}$; therefore the DMA aerosol flow required a large dilution. (2) Conventionally, the PILS instrument samples with a cyclone with a 1 or $2.5 \mu \mathrm{m}$ cutoff, which is similar to other mass measurement instruments including the aerosol mass spectrometer (AMS) and filter collection.

Figure 8 shows the aerosol nitrate (blue) trace from $\mathrm{NaNO}_{3}$ particles measured by the PILS-ESI/MS shifted in time to account for the system delay time so that it aligns with the relatively steady concentration periods with the $\mathrm{N}_{\mathrm{r}}$ trace (black). The PILS-ESI/MS had a response time of roughly 4-5 min in its current configuration. Several stages in the PILS system included mixing volumes (e.g., syringe pumps and mixing vessels) that prevented rapid response to rapidly changing concentrations and smeared the response. For instrument comparisons $60 \mathrm{~s}$ data were averaged and compared during periods with relatively steady concentrations (generally lasting 5-10 min). Examples of PILS-ESI/MS traces aligned such that the initial response of both instruments coincides and is shown in Fig. S2.

The correlation plot of PILS-ESI/MS to equivalent anion mass measured as $\mathrm{N}_{\mathrm{r}}$ for each aerosol type $\left(\mathrm{NaNO}_{3}\right.$, $\left(\mathrm{NH}_{4}\right)_{2} \mathrm{SO}_{4}, \mathrm{NH}_{4} \mathrm{Cl}$, and $\left.\mathrm{NH}_{4} \mathrm{NO}_{3}\right)$ is shown in Fig. 9a-d. The concentrations ranged from $\sim 10$ to $120 \mu \mathrm{g} \mathrm{m}^{-3}$ and the 


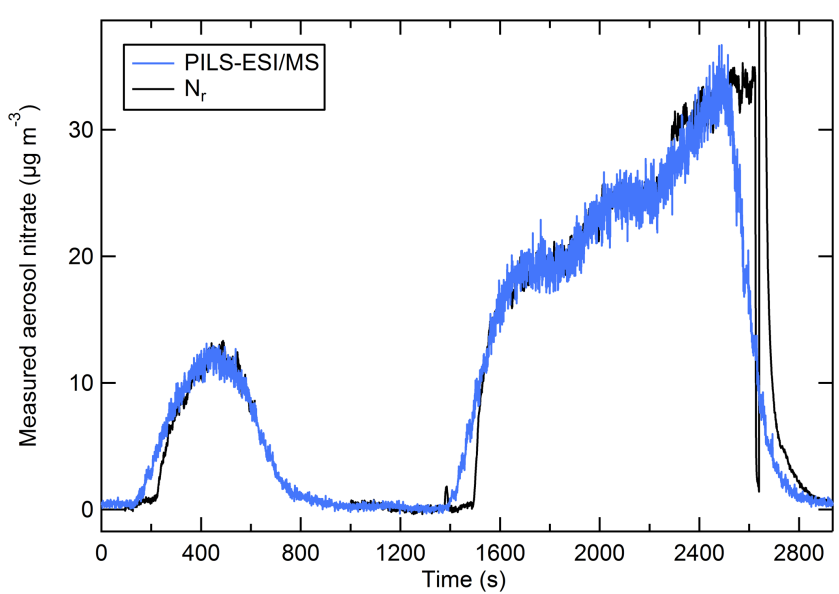

Figure 8. The PILS-ESI/MS-measured aerosol nitrate mass (blue) and the nitrate measured as $\mathrm{N}_{\mathrm{r}}$ (black) $\left(\mu \mathrm{g} \mathrm{m}^{-3}\right)$ for an atomized solution of $\mathrm{NaNO}_{3}$ (polydisperse). The PILS-ESI/MS trace is shifted to account for the delayed response and the instrument time constant.

standard linear regression fits for each aerosol type are included in Fig. 9, and were highly correlated with a $R^{2}=0.99$. For $\left(\mathrm{NH}_{4}\right)_{2} \mathrm{SO}_{4}$, the concentration exceeded the linear dynamic range of the PILS-ESI/MS for sulfate (see Fig. S2a; $>130 \mu \mathrm{g} \mathrm{m}^{-3}$ ) as determined by liquid-standard calibration curves. The linear range of ESI is limited at high concentrations due to limited surface sites available for ionization (Tang et al., 2004). For this reason values outside the linear dynamic range of the PILS-ESI/MS $\left(>130 \mu \mathrm{g} \mathrm{m}^{-3}\right)$ for sulfate were excluded from the linear regression fit. $\mathrm{NH}_{4} \mathrm{NO}_{3}$ shows a similar, less pronounced trend; however, it is still included in the regression plot as it was difficult to isolate whether this was analyte suppression during electrospray ionization or a linear dynamic range issue. Based on the regression fits in Fig. 9, the difference between the PILSESI/MS and $\mathrm{N}_{\mathrm{r}}$ system for each inorganic component is less than $6 \%$. The uncertainty in the ESI signal varies by compound and averaging time; however from the tests described here the maximum uncertainty is estimated at $\sim 15 \%$. Combining this uncertainty with the uncertainty in the ESI calibrations (maximum $\pm 10 \%$ ), the air and liquid flow rate (both $\sim \pm 4 \%$ ) and dilution $(\sim \pm 5 \%)$ in quadrature gives a total maximum uncertainty associated with mass measurements of $\pm 20 \%$. Thus, while the slope of the correlations of the two instruments (based on $60 \mathrm{~s}$ averages during periods with constant concentrations) shows a relative difference of less than $\sim 6 \%$, the uncertainty in the PILS/ESI measurement of single-component aerosols is closer to $\sim 20 \%$ and could be greater if the transmission and ionization efficiencies of the ESI differ from the efficiencies present during calibration periods. This uncertainty is greater than the uncertainty $( \pm 10 \%)$ reported for the PILS-IC instrument for ionic species in Weber et al. (2001) but lower than the AMS

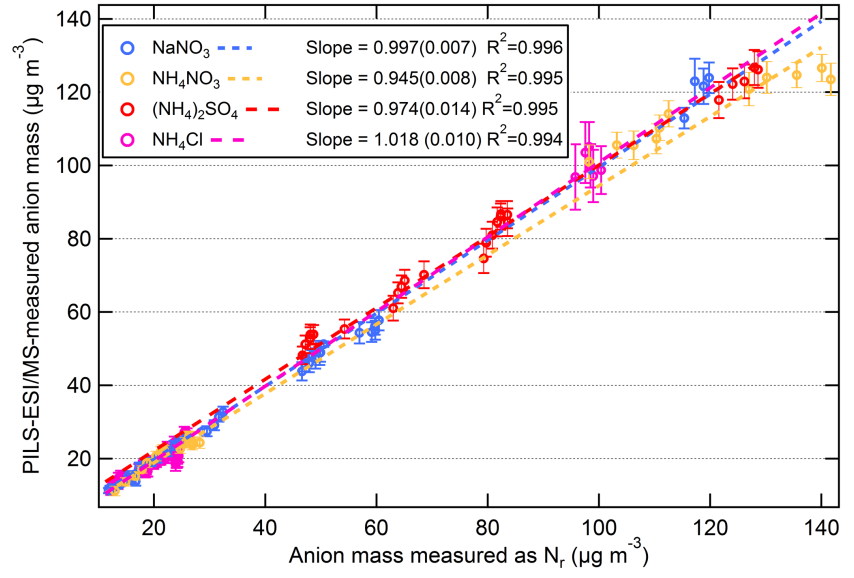

Figure 9. Scatter plots of PILS-ESI/MS measured versus equivalent anion mass measured as $\mathrm{N}_{\mathrm{r}}$ for salts $\mathrm{NaNO}_{3}$ (blue), $\mathrm{NH}_{4} \mathrm{NO}_{3}$ (gold), $\left(\mathrm{NH}_{4}\right)_{2} \mathrm{SO}_{4}$ (red), and $\mathrm{NH}_{4} \mathrm{Cl}$ (magenta). The data are $60 \mathrm{~s}$ averages and only include times when the atomized aerosol output was relatively constant (i.e., not when concentrations were rising or falling). The slope $(1 \sigma)$ and $R^{2}$ are shown.

uncertainty for nitrate $(33 \%)$ and sulfate $(35 \%)$ estimated by Bahreini et al. (2009), though the AMS has a much faster time response.

Even though greater aerosol particle mass could be produced by directly sampling the polydisperse output of the atomizer, our analysis also included measurements using the DMA size-selected output. During these tests the flow was divided between the $\mathrm{N}_{\mathrm{r}}$ system, CPC, UHSAS, and PILSESI/MS with a large dilution flow that resulted in turbulent mixing $(\operatorname{Re}>4000)$. The CPC and UHSAS particle number concentrations showed improved agreement with turbulent mixing compared to earlier differences of up to $10 \%$ at high concentrations discussed in Sect. 2.2.2 and were within a few percent of each other. Examples of the real-time temporal profiles for these measurements are shown in Fig. 10a-d with the PILS-ESI/MS time offset by several minutes to account for its delayed response. The calculated and measured aerosol mass time traces in Fig. 10 show agreement for all measurement techniques tested in this study. The figures indicate that the PILS-ESI/MS was not given sufficient time to rise to a steady constant concentration for the first diameter selected. This is confirmed in Fig. 10b when $200 \mathrm{~nm}$ particles were size selected twice in succession, with the first selection lasting only $\sim 2$ min before flushing with water quickly followed by a longer period of sampling at the same diameter. The PILS-ESI/MS concentration during this longer sampling period does reach the expected concentration as indicated by the $\mathrm{N}_{\mathrm{r}}$ (black) and CPC (blue) concentrations. The time series of oxalate in Fig. 10d shows agreement for the equivalent $\mathrm{N}_{\mathrm{r}}$ - and PILS-ESI/MS-measured mass, indicating these same calibration methods are effective for organic compounds, although the UHSAS was not sampling during 

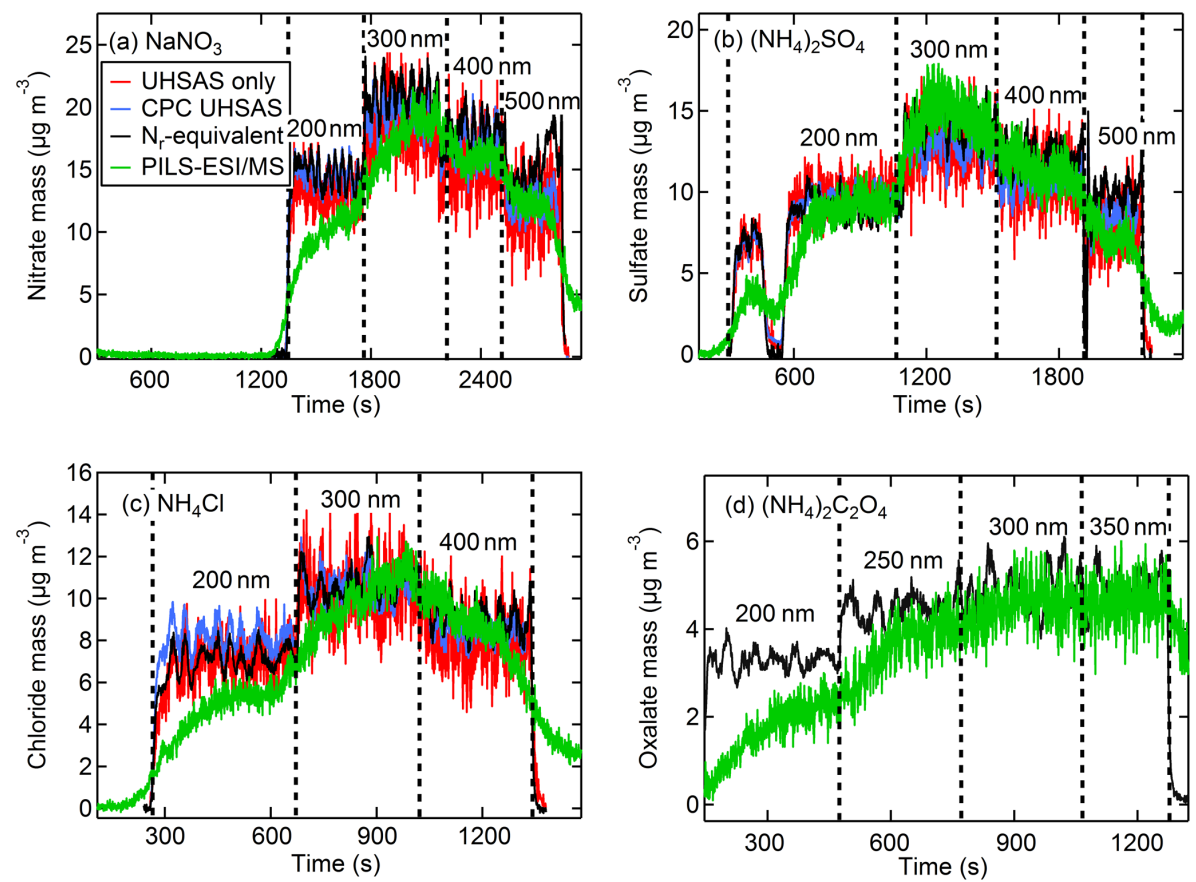

Figure 10. The $\mathrm{N}_{\mathrm{r}}$-measured (black) CPC number with UHSAS size (blue) calculated, UHSAS number and size (red) calculated, and PILSESI/MS-measured (green) aerosol concentrations $\left(\mu \mathrm{g} \mathrm{m}{ }^{-3}\right)$ for anions of DMA size-selected aerosol for salts of $(\mathbf{a}) \mathrm{NaNO}_{3}$, $(\mathbf{b})\left(\mathrm{NH}_{4}\right)_{2} \mathrm{SO}_{4}$, (c) $\mathrm{NH}_{4} \mathrm{Cl}$, and (d) $\left(\mathrm{NH}_{4}\right)_{2} \mathrm{C}_{2} \mathrm{O}_{4}$. The PILS-ESI/MS traces were shifted in time several minutes early to account for the delayed instrument response time.

this experiment. We conclude that the PILS-ESI/MS quantitatively measures single-component inorganic aerosol for a range of sizes; however, the low particle throughput hindered our ability to evaluate the quantitative abilities of the PILSESI/MS system for particles $<200 \mathrm{~nm}$ diameter.

These results establish the quantitative abilities of this novel configuration (PILS-ESI/MS) for sampling simple single-component laboratory-generated aerosol. However, our current ESI/MS calibration methods are sensitive to the experimental conditions, which must be precisely maintained during ESI calibrations and throughout the entire sampling period. Changes in flow rate, interface positioning, or solvent composition have significant impacts on both the transmission and ionization efficiency, ultimately effecting predetermined ESI calibration factors. In general, PILS characterization has been limited to theoretical predictions or experimental comparisons that involve coupling the PILS with a mass analyzer (e.g., IC; Orsini et al., 2003; Sorooshian et al., 2006). Here we show experimentally that the $\mathrm{N}_{\mathrm{r}}$ system can be used as a mass calibration method for pure $\mathrm{N}_{\mathrm{r}}$-containing polydisperse aerosol.

\section{Summary and conclusions}

We report the successful application of a total reactive nitrogen $\left(\mathrm{N}_{\mathrm{r}}\right)$ system for conversion of gas-phase and particlebound $\mathrm{N}_{\mathrm{r}}$ compounds. The $\mathrm{N}_{\mathrm{r}}$ system was tested using laboratory-generated aerosol from solutions of $\left(\mathrm{NH}_{4}\right)_{2} \mathrm{SO}_{4}$, $\mathrm{NH}_{4} \mathrm{Cl}, \mathrm{NaNO}_{3}$, and $\left(\mathrm{NH}_{4}\right)_{2} \mathrm{C}_{2} \mathrm{O}_{4}$. The particle conversion efficiency of each compound was calculated at each sizeselected diameter by the ratio of the concentration measured as $\mathrm{N}_{\mathrm{r}}$ to mass concentrations calculated from number concentration and size distribution measurements using a CPC and UHSAS. Overall, the particle conversion efficiency for a selection of $\mathrm{N}_{\mathrm{r}}$-containing aerosols ranged from 93 to $101 \%$ with an overall estimated uncertainty of $\sim 10 \%$. The $\mathrm{N}_{\mathrm{r}}$ particles tested span the range of $\mathrm{N}$ oxidation states, and therefore we are confident these results extend to other $\mathrm{N}_{\mathrm{r}^{-}}$ containing particles. Most catalyst-based $\mathrm{N}_{\mathrm{r}}$ systems measure total gas-phase $\mathrm{N}_{\mathrm{r}}$-only, individual $\mathrm{N}_{\mathrm{r}}$ compounds (e.g., $\mathrm{NH}_{3}$ ), or ignore the contribution of particulate $\mathrm{N}_{\mathrm{r}}$ to total signal completely. However, it is useful to measure the total unspeciated $\mathrm{N}_{\mathrm{r}}$ signal, which includes both gases and particles, to improve our understanding of total $\mathrm{N}$ emissions and their deposition, loss, and availability in ecosystems (e.g., McCalley and Sparks, 2009). We have presented a rapid, robust measurement technique that quantitatively measures particle $\mathrm{N}_{\mathrm{r}}$ mass that allows for accurately interpreting ambient measurements and allows improved mass closure of the $\mathrm{N}$ budget to be constructed for the 2016 Fire Sciences Laboratory measurements of wildfire emissions. Future applications of this custom system aim to distinguish gas- and particle-phase nitrogen contributions from total measured $\mathrm{N}_{\mathrm{r}}$ signal using upstream filters and denuders. 
Additional characterization tests showed the platinum catalyst in the $\mathrm{N}_{\mathrm{r}}$ system quantitatively converts both gaseousand particulate-organic carbon (OC) to $\mathrm{CO}_{2}$ to within the propagated uncertainties of each detection method $( \pm 10 \%$ each). The resulting $\mathrm{N}_{\mathrm{r}}$ and $\mathrm{C}_{y}$ signals from each detector are in proportion with the number of carbon and nitrogen atoms in the parent molecule. In order for this to be a reliable total particulate carbon measurement system under ambient conditions, a highly accurate and precise $\mathrm{CO}_{2}$ measurement system is imperative to measure the signal above ambient $\mathrm{CO}_{2}$, $\mathrm{CO}$, and $\mathrm{CH}_{4}$ backgrounds. Alternatively, ambient gas-phase constituents could be effectively eliminated from the sampling matrix. For these reasons, the application of the system is currently limited to calibration of single-component OCand/or $\mathrm{N}_{\mathrm{r}}$-containing particles.

After establishing efficient conversion of $\mathrm{N}_{\mathrm{r}}$ particles, we experimentally demonstrated that the $\mathrm{N}_{\mathrm{r}}$ conversion technique can be used to calibrate aerosol particle mass measurement methods when sampling pure $\mathrm{N}_{\mathrm{r}}$-containing polydisperse aerosol. The $\mathrm{N}_{\mathrm{r}}$ equivalent mass measurements of pure atomized polydisperse aerosol showed an agreement within $\pm 6 \%$ with the PILS-ESI/MS measurements of the corresponding anion for the salts $\left(\mathrm{NH}_{4}\right)_{2} \mathrm{SO}_{4}, \mathrm{NH}_{4} \mathrm{Cl}, \mathrm{NaNO}_{3}$, and $\mathrm{NH}_{4} \mathrm{NO}_{3}$. There is a clear advantage to calibrating the entire PILS-ESI/MS system altogether as this avoids complications arising from calibrating the ESI/MS and PILS independently. We conclude that the $\mathrm{N}_{\mathrm{r}}$ system is an effective measurement technique that can be used to directly calibrate aerosol mass measurement instruments. With this direct mass calibration method, complications that arise due to optical (e.g., refractive index) and physical properties (e.g., morphologies) in particle number calibration methods are avoided. Additionally, this method is an online technique that provides a rapid measurement of particle mass unlike offline mass measurement methods such as filter analyses. The $\mathrm{N}_{\mathrm{r}}$ converter described followed by $\mathrm{NO}$ and $\mathrm{CO}_{2}$ detection constitute a viable new approach for calibrating aerosol mass instrumentation for both $\mathrm{N}$-containing and organic carbon particles.

Data availability. The data from the laboratory tests are available on request. Data from the 2016 Missoula Fire lab are available here: https://esrl.noaa.gov/csd/groups/csd7/measurements/ 2016firex/FireLab/DataDownload/index.php?page=/csd/groups/ csd7/measurements/2016firex/FireLab/DataDownload/ (National Oceanic and Atmospheric Administration, 2018). Authentication is required until approximately November 2018 and can be obtained by contacting either corresponding author.

Supplement. The supplement related to this article is available online at: https://doi.org/10.5194/amt-11-2749-2018-supplement.
Author contributions. CES wrote the paper with help from JMR. CES performed the particle calibrations with help from RAW and AK. JMR and YL built the $\mathrm{N}_{\mathrm{r}}$ catalyst and performed the tests to verify gas-phase conversion of $\mathrm{N}_{\mathrm{r}}$ species. AMM advised on operation of the PILS. BW, RKT, and CES designed, constructed, and characterized the ESI interface. VS, RJY, KJZ, CW, and KS made measurements of individual $\mathrm{N}$ species during the FIREX campaign.

Competing interests. The authors declare that they have no conflict of interest.

Disclaimer. Mention of commercial products is for identification purposes only and does not imply endorsements.

Acknowledgements. This work was supported by NOAA's Climate and Health of the Atmosphere initiatives. Chelsea E. Stockwell acknowledges support from the National Research Council Research Associateship Program. Bartlomiej Witkowski was supported by the Kościuszko Foundation Program for Advanced Study, Research and/or Teaching in the United States 2014-2015. Agnieszka Kupc is supported by the Austrian Science Fund FWF's Erwin Schrodinger Fellowship J-3613. The FIREX Fire Lab study was supported in part by the NOAA Climate Office's Atmospheric Chemistry, Carbon Cycle, and Climate program. We thank Brad Hall for the use of his nitrous oxide standard. We thank Staci N. Anthony and the Jarrold Group for giving us an ion carpet board for the ESI interface. We thank Matthew Coggon, Abigail Koss, and Joost de Gouw for their $\mathrm{H}_{3} \mathrm{O}^{+}$CIMS data and Steven Brown for his cavity-enhanced spectrometer data. We would like to thank Katherine Manfred, Alessandro Franchin, and Charles Brock for their useful discussions.

Edited by: Hartmut Herrmann

Reviewed by: Jeffrey Collett and one anonymous referee

\section{References}

Anthony, S. N., Shinholt, D. L., and Jarrold, M. F.: A simple electrospray interface based on a DC ion carpet, Int. J. Mass Spectrom., 371, 1-7, https://doi.org/10.1016/j.ijms.2014.06.007, 2014.

Bahreini, R., Ervens, B., Middlebrook, A. M., Warneke, C., de Gouw, J. A., DeCarlo, P. F., Jimenez, J. L., Brock, C. A., Neuman, J. A., Ryerson, T. B., Stark, H., Atlas, E., Brioude, J., Fried, A., Holloway, J. S., Peischl, J., Richter, D., Walega, J., Weibring, P., Wollny, A. G., and Fehsenfeld, F. C.: Organic aerosol formation in urban and industrial plumes near Houston and Dallas, Texas, J. Geophys. Res., 114, D00F16, https://doi.org/10.1029/2008JD011493, 2009.

Bauer, S. E., Koch, D., Unger, N., Metzger, S. M., Shindell, D. T., and Streets, D. G.: Nitrate aerosols today and in 2030: a global simulation including aerosols and tropospheric ozone, Atmos. Chem. Phys., 7, 5043-5059, https://doi.org/10.5194/acp-7-50432007, 2007.

Bellouin, N., Rae, J., Jones, A., Johnson, C., Haywood, J., and Boucher, O.: Aerosol forcing in the Climate Model Intercom- 
parison Project (CMIP5) simulations by HadGEM2-ES and the role of ammonium nitrate, J. Geophys. Res., 116, D20206, https://doi.org/10.1029/2011JD016074, 2011.

Benedict, K. B., Prenni, A. J., Carrico, C. M., Sullivan, A. P., Schichtel, B. A., and Collett Jr., J. L.: Enhanced concentrations of reactive nitrogen species in wildfire smoke, Atoms. Environ., 148, 8-15, https://doi.org/10.1016/j.atmosenv.2016.10.030, 2017.

Bohren, C. F. and Huffman, D. R.: Absorption and scattering of light by small particles, Wiley, New York, USA, 1983.

Breitenbach, L. P. and Shelef, M.: Development of a method for the analysis of $\mathrm{NO}_{2}$ and $\mathrm{NH}_{3}$ by NO-measuring instruments, J. Air Pollut. Contr. Assoc., 23, 128-131, https://doi.org/10.1080/00022470.1973.10469752, 1973.

Burling, I. R., Yokelson, R. J., Griffith, D. W. T., Johnson, T. J., Veres, P., Roberts, J. M., Warneke, C., Urbanski, S. P., Reardon, J., Weise, D. R., Hao, W. M., and de Gouw, J.: Laboratory measurements of trace gas emissions from biomass burning of fuel types from the southeastern and southwestern United States, Atmos. Chem. Phys., 10, 11115-11130, https://doi.org/10.5194/acp-10-11115-2010, 2010.

Cai, Y., Montague, D. C., Mooiweer-Bryan, W., and Deshler, T.: Performance characteristics of the ultra high sensitivity aerosol spectrometer for particles between 55 and $800 \mathrm{~nm}$ : Laboratory and field studies, J. Aerosol Sci., 39, 759-769, https://doi.org/10.1016/j.jaerosci.2008.04.007, 2008.

Canagaratna, M. R., Jayne, J. T., Jimenez, J. L., Allan, J. D., Alfarra, M. R., Zhang, Q., Onasch, T. B., Drewnick, F., Coe, H., Middlebrook, A., Delia, A., Williams, L. R., Trimborn, A. M., Northway, M. J., DeCarlo, P. F., Kolb, C. E., Davidovits, P., and Worsnop, D. R.: Chemical and microphysical characterization of ambient aerosols with the Aerodyne aerosol mass spectrometer, Mass Spectrom. Rev., 26, 185-222, https://doi.org/10.1002/mas.20115, 2007.

Cape, J. N., Cornell, S. E., Jickells, T. D., and Nemitz, E.: Organic nitrogen in the atmosphere-Where does it come from? A review of sources and methods, Atmos. Res., 102, 30-48, https://doi.org/10.1016/j.atmosres.2011.07.009, 2011.

Chen, B., T., Fletcher, R. A., and Cheng, Y.,-S.: Calibration of Aerosol Instruments, in: Aerosol Measurement: Principles, Techniques, and Applications, Third Edition, edited by: Kulkarni, P., Baron, P. A., and Willeke, K., John Wiley \& Sons, Inc., Hoboken, NJ, USA, https://doi.org/10.1002/9781118001684.ch21, 2011.

Collins, D. R., Flagan, R. C., and Seinfeld, J. H.: Improved inversion of scanning DMA data, Aerosol Sci. Tech., 36, 1-9, https://doi.org/10.1080/027868202753339032, 2002.

Cornell, S. E.: Atmospheric nitrogen deposition: revising the question of the importance of the organic component, Environ. Pollut., 159, 2214-2222, https://doi.org/10.1016/j.envpol.2010.11.014, 2010.

DeCarlo, P. F., Slowik, J. G., Worsnop, D. R., Davidovits, P., and Jimenez, J. L.: Particle morphology and density characterization by combined mobility and aerodynamic diameter measurements. Part 1: Theory, Aerosol Sci. Tech., 38, 1185-1205, https://doi.org/10.1080/027868290903907, 2004.

Drewnick, F., Schwab, J. J., Hogrefe, O., Peters, S., Husain, L., Diamnon, D., Weber, R., and Demerjian, K. L.: Intercomparison and evaluation of four semi-continuous
$\mathrm{PM}_{2.5}$ sulfate instruments, Atmos. Environ., 37, 3335-3350, https://doi.org/10.1016/S1352-2310(03)00351-0, 2003.

Dunlea, E. J., Herndon, S. C., Nelson, D. D., Volkamer, R. M., San Martini, F., Sheehy, P. M., Zahniser, M. S., Shorter, J. H., Wormhoudt, J. C., Lamb, B. K., Allwine, E. J., Gaffney, J. S., Marley, N. A., Grutter, M., Marquez, C., Blanco, S., Cardenas, B., Retama, A., Ramos Villegas, C. R., Kolb, C. E., Molina, L. T., and Molina, M. J.: Evaluation of nitrogen dioxide chemiluminescence monitors in a polluted urban environment, Atmos. Chem. Phys., 7, 2691-2704, https://doi.org/10.5194/acp-7-26912007, 2007.

Fahey, D., Eubank, C., Hübler, G., and Fehsenfeld, F.: Evaluation of a catalytic reduction technique for the measurement of total reactive odd-nitrogen NOy in the atmosphere, J. Atmos. Chem., 3, 435-468, https://doi.org/10.1007/BF00053871, 1985.

Fahey, D. W., Hübler, G., Parrish, D. D., Williams, E. J., Norton, R. B., Ridley, B. A., Singh, H. B., Liu, S. C., and Fehsenfeld, F. C.: Reactive nitrogen species in the troposphere: Measurements of $\mathrm{NO}, \mathrm{NO}_{2}, \mathrm{HNO}_{3}$, particulate nitrate, peroxyacetyl nitrate (PAN), $\mathrm{O}_{3}$, and total reactive odd nitrogen $\left(\mathrm{NO}_{y}\right)$ at Niwot Ridge, Colorado, J. Geophys. Res., 91, 9781-9793, https://doi.org/10.1029/JD091iD09p09781, 1986.

Farmer, D. K., Matsunaga, A., Docherty, K. S., Surratt, J. D., Seinfeld, J. H., Ziemann, P. J., and Jimenez, J. L.: Response of an aerosol mass spectrometer to organonitrates and organosulfates and implications for atmospheric chemistry, P. Natl. Acad. Sci. USA, 107, 6670-6675, https://doi.org/10.1073/pnas.0912340107, 2010.

Forster, P., Ramaswamy, V., Artaxo, P., Berntsen, T., Betts, R., Fahey, D. W., Haywood, J., Lean, J., Lowe, D. C., Myhre, G., Nganga, J., Prinn, R., Raga, G., Schulz, M., and Van Dorland, R.: Changes in Atmospheric Constituents and in Radiative Forcing, in: Climate Change 2007: The Physical Science Basis. Contribution of Working Group I to the Fourth Assessment Report of the Intergovernmental Panel on Climate Change, edited by: Solomon, S., Qin, D., Manning, M., Chen, Z., Marquis, M., Averyt, K. B., Tignor, M., and Miller, H. L., Cambridge University Press, Cambridge, UK and New York, NY, USA, 2007.

Froyd, K. D.: Ion induced nucleation in the atmosphere: Studies of ammonia, sulfuric acid, and water cluster ions, $\mathrm{PhD}$, Department of Chemistry, University of Colorado, Boulder, Colorado, USA, 282 pp., 2002.

Fuzzi, S., Baltensperger, U., Carslaw, K., Decesari, S., Denier van der Gon, H., Facchini, M. C., Fowler, D., Koren, I., Langford, B., Lohmann, U., Nemitz, E., Pandis, S., Riipinen, I., Rudich, Y., Schaap, M., Slowik, J. G., Spracklen, D. V., Vignati, E., Wild, M., Williams, M., and Gilardoni, S.: Particulate matter, air quality and climate: lessons learned and future needs, Atmos. Chem. Phys., 15, 8217-8299, https://doi.org/10.5194/acp15-8217-2015, 2015.

Griffith, D. W. T., Mankin, W. G., Coffey, M. T., Ward, D. E., and Riebau, A.: FTIR remote sensing of biomass burning emissions of $\mathrm{CO}_{2}, \mathrm{CO}, \mathrm{CH}_{4}, \mathrm{CH}_{2} \mathrm{O}, \mathrm{NO}, \mathrm{NO}_{2}, \mathrm{NH}_{3}$, and $\mathrm{N}_{2} \mathrm{O}$, in: Global Biomass Burning: Atmospheric, Climatic, and Biospheric Implications, edited by: Levine, J. S., MIT Press, Cambridge, MA, USA, 230-239, 1991.

Hallquist, M., Wenger, J. C., Baltensperger, U., Rudich, Y., Simpson, D., Claeys, M., Dommen, J., Donahue, N. M., George, C., Goldstein, A. H., Hamilton, J. F., Herrmann, H., Hoff- 
mann, T., Iinuma, Y., Jang, M., Jenkin, M. E., Jimenez, J. L., Kiendler-Scharr, A., Maenhaut, W., McFiggans, G., Mentel, Th. F., Monod, A., Prévôt, A. S. H., Seinfeld, J. H., Surratt, J. D., Szmigielski, R., and Wildt, J.: The formation, properties and impact of secondary organic aerosol: current and emerging issues, Atmos. Chem. Phys., 9, 5155-5236, https://doi.org/10.5194/acp9-5155-2009, 2009.

Hand, J. L. and Kreidenweis, S. M.: A new method for retrieving particle refractive index and effective density from aerosol size distribution data, Aerosol Sci. Tech., 36, 1012-1026, https://doi.org/10.1080/02786820290092276, 2002.

Hardy, J. E. and Knarr, J. J.: Technique for measuring the total concentration of gaseous fixed nitrogen species, J. Air Pollut. Contr. Assoc., 32, 376-379, https://doi.org/10.1080/00022470.1982.10465412, 1982.

Hauglustaine, D. A., Balkanski, Y., and Schulz, M.: A global model simulation of present and future nitrate aerosols and their direct radiative forcing of climate, Atmos. Chem. Phys., 14, 1103111063, https://doi.org/10.5194/acp-14-11031-2014, 2014.

Haywood, J., Bush, M., Abel, S., Claxton, B., Coe, H., Crosier, J., Harrison, M., Macpherson, B., Naylor, M., and Osborne, S.: Prediction of visibility and aerosol within the operational Met Office Unified Model II: Validation of model performance using observational data, Q. J. Roy. Meteor. Soc., 134, 1817-1832, https://doi.org/10.1002/qj.275, 2008.

Horstman, D. W.: A technique for measuring total oxides of nitrogen and ammonia by chemiluminescent detection, Analysis Instr., edited by: Iverson, A., Instrument Society of America, Research Triangle Park, USA, 93-98, 1982.

$\mathrm{Hu}, \mathrm{D}$., Chen, J., Ye, X., and Yang, X.: Hygroscopicity and evaporation of ammonium chloride and ammonium nitrate: Relative humidity and size effects on the growth factor, Atmos. Environ., 45, 2349-2355, https://doi.org/10.1016/j.atmosenv.2011.02.024, 2011.

Huffman, J. A., Docherty, K. S., Aiken, A. C., Cubison, M. J., U1brich, I. M., DeCarlo, P. F., Sueper, D., Jayne, J. T., Worsnop, D. R., Ziemann, P. J., and Jimenez, J. L.: Chemically-resolved aerosol volatility measurements from two megacity field studies, Atmos. Chem. Phys., 9, 7161-7182, https://doi.org/10.5194/acp9-7161-2009, 2009.

IPCC: Climate Change 2013, The Physical Science Basis, Bern, Switzerland, 2013.

Jayne, J. T., Leard, D. C., Zhan, X., Davidovits, P., Smith, K. A., Kolb, C. E., and Worsnop, D. R.: Development of an aerosol mass spectrometer for size and composition analysis of submicron particles, Aerosol Sci. Tech., 33, 49-70, https://doi.org/10.1080/027868200410840, 2000.

Jickells, T., Baker, A., R., Cape, J., N., Cornell, S., E., and Nemitz, E.: The cycling of organic nitrogen through the atmosphere, Philos. T. R. Soc. Lon. B, 368, 1621, https://doi.org/10.1098/rstb.2013.0115, 2013.

Jimenez, J. L., Canagaratna, M. R., Donahue, N. M., Prevot, A. S. H., Zhang, Q., Kroll, J. H., DeCarlo, P. F., Allan, J. D., Coe, H., Ng, N. L., Aiken, A. C., Docherty, K. S., Ulbrich, I. M., Grieshop, A. P., Robinson, A. L., Duplissy, J., Smith, J. D., Wilson, K. R., Lanz, V. A., Hueglin, C., Sun, Y. L., Tian, J., Laaksonen, A., Raatikainen, T., Rautiainen, J., Vaattovaara, P., Ehn, M., Kulmala, M., Tomlinson, J. M., Collins, D. R., Cubison, M. J., Dunlea, E. J., Huffman, J. A., Onasch, T. B., Al- farra, M. R., Williams, P. I., Bower, K., Kondo, Y., Schneider, J., Drewnick, F., Borrmann, S., Weimer, S., Demerjian, K., Salcedo, D., Cottrell, L., Griffin, R., Takami, A., Miyoshi, T., Hatakeyama, S., Shimono, A., Sun, J. Y., Zhang, Y. M., Dzepina, K., Kimmel, J. R., Sueper, D., Jayne, J. T., Herndon, S. C., Trimborn, A. M., Williams, L. R., Wood, E. C., Middlebrook, A. M., Kolb, C. E., Baltensperger, U., and Worsnop, D. R.: Evolution of organic aerosols in the atmosphere, Science, 326, 1525-1529, https://doi.org/10.1126/science.1180353, 2009.

Jimenez, J. L., Canagaratna, M. R., Drewnick, F., Allan, J. D., Alfarra, M. R., Middlebrook, A. M., Slowik, J. G., Zhang, Q., Coe, H., Jayne, J. T., and Worsnop, D. R.: Comment on "The effects of molecular weight and thermal decomposition on the sensitivity of a thermal desorption aerosol mass spectrometer", Aerosol Sci. Tech., 50, i-xv, https://doi.org/10.1080/02786826.2016.1205728, 2016.

Kamal, M. S., Razzak, S. A., and Hossain, M. M.: Catalytic oxidation of volatile organic compounds (VOCs) - A review, Atmos. Environ., 140, 117-134, https://doi.org/10.1016/j.atmosenv.2016.05.031, 2016.

Kiyoura, R. and Urano, K.: Mechanism, kinetics and equilibrium of thermal decomposition of ammonium sulfate, Ind. Eng. Chem. Proc. DD, 9, 489-494, https://doi.org/10.1021/i260036a001, 1970.

Knutson, E. O. and Whitby, K. T.: Aerosol classification by electric mobility: Apparatus, theory, and applications, J. Aerosol Sci., 6 , 443-451, https://doi.org/10.1016/0021-8502(75)90060-9, 1975.

Koss, A. R., Sekimoto, K., Gilman, J. B., Selimovic, V., Coggon, M. M., Zarzana, K. J., Yuan, B., Lerner, B. M., Brown, S. S., Jimenez, J. L., Krechmer, J., Roberts, J. M., Warneke, C., Yokelson, R. J., and de Gouw, J.: Non-methane organic gas emissions from biomass burning: identification, quantification, and emission factors from PTR-ToF during the FIREX 2016 laboratory experiment, Atmos. Chem. Phys., 18, 3299-3319, https://doi.org/10.5194/acp-18-3299-2018, 2018.

Kostiainen, R. and Kauppila, T. J.: Effect of eluent on the ionization process in liquid chromatographymass spectrometry, J. Chrom. A., 1216, 685-699, https://doi.org/10.1016/j.chroma.2008.08.095, 2009.

Kuhlbusch, T. A., Lobert, J. M., Crutzen, P. J., and Warneck, P.: Molecular nitrogen emissions from denitrifcation during biomass burning, Nature, 351, 135-137, https://doi.org/10.1038/351135a0, 1991.

Kupc, A., Williamson, C., Wagner, N. L., Richardson, M., and Brock, C. A.: Modification, calibration, and performance of the Ultra-High Sensitivity Aerosol Spectrometer for particle size distribution and volatility measurements during the Atmospheric Tomography Mission (ATom) airborne campaign, Atmos. Meas. Tech., 11, 369-383, https://doi.org/10.5194/amt-11-369-2018, 2018.

Lee, B. H., Mohr, C., Lopez-Hilfiker, F. D., Lutz, A., Hallquist, M., Lee, L., Romer, P., Cohen, R. C., Iyer, S., Kurten, T., Hu, W. W., Day, D. A., Campuzano-Jost, P., Jimenez, J. L., Xu, L., Ng, N. L., Guo, H., Weber, R. J., Wild, R. J., Brown, S S., Koss, A., de Gouw, J., Olson, K., Goldstein, A. H., Seco, R., Kim, S., McAvey, K. M., Shepson, P. B., Starn, T., Baumann, K., Edgerton, E., Liu, J., Shilling, J. E., Miller, D. O., Brune, W. H., Schobesberger, S., D'Ambro, E. L., and Thornton, J. A.: Highly functionalized organic nitrates in the South- 
east U.S.: contribution to secondary organic aerosol and reactive nitrogen budgets, P. Natl. Acad. Sci. USA, 113, 1516-1521, https://doi.org/10.1073/pnas.1508108113, 2016.

Li, J., Wang, W-C., Liao, H., and Chang, W.: Past and future direct radiative forcing of nitrate aerosol in East Asia, Theor. Appl. Climatol., 121, 445-458, https://doi.org/10.1007/s00704-014-1249$1,2015$.

Liao, H., Adams, P. J., Chung, S. H., Seinfeld, J. H., Mickley, L. J., and Jacob, D. J.: Interactions between tropospheric chemistry and aerosols in a unified general circulation model, J. Geophys. Res., 108, 4001, https://doi.org/10.1029/2001JD001260, 2003.

Lin, M., Walker, J., Geron, C., and Khlystov, A.: Organic nitrogen in $\mathrm{PM}_{2.5}$ aerosol at a forest site in the Southeast US, Atmos. Chem. Phys., 10, 2145-2157, https://doi.org/10.5194/acp10-2145-2010, 2010.

Liu, Y. and Daum, P. H.: The effect of refractive index on size distributions and light scattering coefficients derived from optical particle counters, J. Aerosol Sci., 31, 945-957, https://doi.org/10.1016/S0021-8502(99)00573-X, 2000.

Liu, B. Y. H. and Lee, K.W.: An aerosol generator of high stability, Am. Ind. Hyg. Assoc. J., 36, 861-865, https://doi.org/10.1080/0002889758507357, 1975.

Lobert, J. M., Scharffe, D. H., Hao, W.-M., and Crutzen, P. J.: Importance of biomass burning in the atmospheric budgets of nitrogen-containing gases, Nature, 346, 552-554, https://doi.org/10.1038/346552a0, 1990.

Lobert, J. M., Scharffe, D. H., Hao, W.-M., Kuhlbusch, T. A., Seuwen, R., Warneck, P., and Crutzen, P. J.: Experimental evaluation of biomass burning emissions: Nitrogen and carbon containing compounds. In: Global Biomass Burning: Atmospheric, Climatic, and Biospheric Implications, edited by: Levine, J. S., The MIT Press, Cambridge, MA, USA, 1991.

Lovejoy, E. R.: Ion trap studies of $\mathrm{H}^{+}\left(\mathrm{H}_{2} \mathrm{SO}_{4}\right)_{m}\left(\mathrm{H}_{2} \mathrm{O}\right)_{n}$ reactions with water, ammonia, and a variety of organic compounds, Int. J. Mass Spectrom., 190/191, 231-241, 1999.

Ma, Y.: Developments and Improvements to the Particle-IntoLiquid Sampler (PILS) and its Application to Asian Outflow Studies, PhD Dissertation, Georgia Institute of Technology, Atlanta, GA, USA, 2004.

Maris, C., Chung, M. Y., Lueb, R., Krischke, U., Meller, R., Fox, M. J., and Paulson, S. E.: Development of instrumentation for simultaneous analysis of total non-methane organic carbon and volatile organic compounds in ambient air, Atmos. Environ., 37, S149S158, https://doi.org/10.1016/S1352-2310(03)00387-X, 2003.

Marx, O., Brümmer, C., Ammann, C., Wolff, V., and Freibauer, A.: TRANC - a novel fast-response converter to measure total reactive atmospheric nitrogen, Atmos. Meas. Tech., 5, 1045-1057, https://doi.org/10.5194/amt-5-1045-2012, 2012.

McCalley, C. K. and Sparks, J. P.: Abiotic gas formation drives nitrogen loss from a desert ecosystem, Science, 326, 837-840, https://doi.org/10.1126/science.1178984, 2009.

McMeeking, G. R., Kreidenweis, S. M., Baker, S., Carrico, C. M., Chow, J. C., Collet Jr., J. L., Hao, W. M., Holden, A. S., Kirchstetter, T. W., Malm, W. C., Moosmüller, H., Sullivan, A. P., and Wold, C. E.: Emissions of trace gases and aerosols during the open combustion of biomass in the laboratory, J. Geophys. Res., 114, D19210, https://doi.org/10.1029/2009JD011836, 2009.

Min, K.-E., Washenfelder, R. A., Dubé, W. P., Langford, A. O., Edwards, P. M., Zarzana, K. J., Stutz, J., Lu, K., Rohrer, F.,
Zhang, Y., and Brown, S. S.: A broadband cavity enhanced absorption spectrometer for aircraft measurements of glyoxal, methylglyoxal, nitrous acid, nitrogen dioxide, and water vapor, Atmos. Meas. Tech., 9, 423-440, https://doi.org/10.5194/amt-9423-2016, 2016.

Murphy, D. M.: The effects of molecular weight and thermal decomposition on the sensitivity of a thermal desorption aerosol mass spectrometer, Aerosol Sci. Tech., 50, 118-125, https://doi.org/10.1080/02786826.2015.1136403, 2016a.

Murphy, D. M.: Reply to Comment on "The effects of molecular weight and thermal decomposition on the sensitivity of a thermal desorption aerosol mass spectrometer", by Jimenez et al., Aerosol Sci. Tech., 50, 1277-1283, 2016b.

Neff, J. C., Holland, E. A., Dentener, F. J., McDowell, W. H., and Russell, K. M.: The origin, composition and rates of organic nitrogen deposition: A missing piece of the nitrogen cycle?, Biogeochemistry, 57, 99-136, 2002.

Neuman, J. A., Huey, L. G., Ryerson, T. B., and Fahey, D. W.: Study of inlet materials for sampling atmospheric nitric acid, Environ. Sci. Technol., 33, 1133-1136, https://doi.org/10.1021/es980767f, 1999.

Neuman, J. A., Ryerson, T. B., Huey, L. G., Jakoubek, R., Nowak, J. B., Simons, G., and Fehsenfeld, F. C.: Calibration and evaluation of nitric acid and ammonia permeation tubes by UV optical absorption, Environ. Sci. Technol., 37, 2975-2981, https://doi.org/10.1021/es0264221, 2003.

NIST: Chemical Kinetics Database, Standard Reference Database 17, Version 7.0 Web Version, available at: https://webbook.nist.gov/chemistry/, last access: 18 September 2017.

National Oceanic and Atmospheric Administration: Fire Lab Study, Earth System Laboratory, Chemical Sciences Division, available at: https://esrl.noaa.gov/csd/groups/csd7/measurements/ 2016firex/FireLab/DataDownload/index.php?page=/csd/groups/ csd7/measurements/2016firex/FireLab/DataDownload/, last access: 6 May 2018.

Orsini, D. A., Ma, Y., Sullivan, A., Sierau, B., Baumann, K., and Weber, R. J.: Refinements to the particle-into-liquid sampler (PILS) for ground and airborne measurements of watersoluble aerosol composition, Atmos. Environ., 37, 1243-1259, https://doi.org/10.1016/S1352-2310(02)01015-4, 2003.

Park, R. S., Lee, S., Shin, S.-K., and Song, C. H.: Contribution of ammonium nitrate to aerosol optical depth and direct radiative forcing by aerosols over East Asia, Atmos. Chem. Phys., 14, 2185-2201, https://doi.org/10.5194/acp-14-2185-2014, 2014.

Parrish, D. D. and Fehsenfeld, F. C.: Methods for gas-phase measurements of ozone, ozone precursors and aerosol precursors, Atmos. Environ., 34, 1921-1957, https://doi.org/10.1016/S13522310(99)00454-9, 2000.

Pöschl, U.: Atmospheric aerosols: Composition, transformation, climate and health effects, Angew. Chem. Int. Edit., 44, 7520 7540, https://doi.org/10.1002/anie.200501122, 2005.

Prenni, A. J., Levin, E. J. T., Benedict, K. B., Sullivan, A. P., Schurman, M. I., Gebhart, K. A., Day, D. E., Carrico, C. M., Malm, W. C., Schichtel, B. A., Collet Jr., J. L., and Kreidenweis, S. M.: Gas-phase reactive nitrogen near Grand Teton National Park: Impacts of transport, anthropogenic emissions, and biomass burning, Atmos. Environ., 89, 749-756, https://doi.org/10.1016/j.atmosenv.2014.03.017, 2014. 
Roberts, J. M., Bertman, S. B., Jobson, T., Niki, H., and Tanner, R.: Measurement of total nonmethane organic carbon $\left(\mathrm{C}_{y}\right)$ : development and application at Chebogue Point, Nova Scotia, during the 1993 North Atlantic Regional Experiment campaign, J. Geophys. Res.-Atmos., 103, 13581-13592, https://doi.org/10.1029/97JD02240, 1998.

Roberts, J. M., Veres, P., Warneke, C., Neuman, J. A., Washenfelder, R. A., Brown, S. S., Baasandorj, M., Burkholder, J. B., Burling, I. R., Johnson, T. J., Yokelson, R. J., and de Gouw, J.: Measurement of HONO, HNCO, and other inorganic acids by negative-ion proton-transfer chemical-ionization mass spectrometry (NI-PT-CIMS): application to biomass burning emissions, Atmos. Meas. Tech., 3, 981-990, https://doi.org/10.5194/amt-3981-2010, 2010.

Rosenberg, P. D., Dean, A. R., Williams, P. I., Dorsey, J. R., Minikin, A., Pickering, M. A., and Petzold, A.: Particle sizing calibration with refractive index correction for light scattering optical particle counters and impacts upon PCASP and CDP data collected during the Fennec campaign, Atmos. Meas. Tech., 5, 1147-1163, https://doi.org/10.5194/amt-5-1147-2012, 2012.

Russell, L. M., Flagan, R. C., and Seinfeld, J. H.: Asymmetric instrument response resulting from mixing effects in accelerated DMA-CPC measurements, Aerosol Sci. Tech., 23, 491-509, https://doi.org/10.1080/02786829508965332, 1995.

Saylor, R. D., Edgerton, E. S., Hartsell, B. E., Baumann, K., and Hansen, D. A.: Continuous gaseous and total ammonia measurements from the southeastern aerosol research and characterization (SEARCH) study, Atmos. Environ., 44, 4994-5004, https://doi.org/10.1016/j.atmosenv.2010.07.055, 2010.

Schwab, J. J., Li, Y., Bae, M.-S., Demerjian, K. L., Hou, J., Zhou, X., Jensen, B., and Pryor, S.: A laboratory intercomparision of real-time gaseous ammonia measurement methods, Environ. Sci. Technol., 41, 8412-8419, https://doi.org/10.1021/es070354r, 2007.

Schwartz, A., Holbrook, L. L., and Wise, H.: Catalytic oxidation studies with platinum and palladium, J. Catal., 21, 199-207, https://doi.org/10.1016/0021-9517(71)90138-2, 1971.

Selimovic, V., Yokelson, R. J., Warneke, C., Roberts, J. M., de Gouw, J., Reardon, J., and Griffith, D. W. T.: Aerosol optical properties and trace gas emissions by PAX and OP-FTIR for laboratory-simulated western US wildfires during FIREX, Atmos. Chem. Phys., 18, 2929-2948, https://doi.org/10.5194/acp18-2929-2018, 2018.

Sorooshian, A., Brechtel, F. J., Ma, Y., Weber, R. J., Corless, A., Flagan, R. C., and Seinfeld, J. H.: Modeling and characterization of a Particle-into-Liquid Sampler (PILS), Aerosol Sci. Tech., 40, 396-409, https://doi.org/10.1080/02786820600632282, 2006.

Stockwell, C. E., Yokelson, R. J., Kreidenweis, S. M., Robinson, A. L., DeMott, P. J., Sullivan, R. C., Reardon, J., Ryan, K. C., Griffith, D. W. T., and Stevens, L.: Trace gas emissions from combustion of peat, crop residue, domestic biofuels, grasses, and other fuels: configuration and Fourier transform infrared (FTIR) component of the fourth Fire Lab at Missoula Experiment (FLAME-4), Atmos. Chem. Phys., 14, 9727-9754, https://doi.org/10.5194/acp-14-9727-2014, 2014.

Stockwell, C. E., Veres, P. R., Williams, J., and Yokelson, R. J.: Characterization of biomass burning emissions from cooking fires, peat, crop residue, and other fuels with high-resolution proton-transfer-reaction time-of-flight mass spectrometry, At- mos. Chem. Phys., 15, 845-865, https://doi.org/10.5194/acp-15845-2015, 2015.

Stolzenburg, M.: An Ultrafine Aerosol Size Distribution Measuring System, PhD thesis, Mechanical Engineering Department, University of Minnesota, Minneapolis, Minnesota, USA, 1988.

Stolzenburg, M. R. and McMurry, P. H.: An ultrafine aerosol condensation nucleus counter, Aerosol Sci. Tech., 14, 48-65, https://doi.org/10.1080/02786829108959470, 1991.

Takegawa, N., Miyazaki, Y., Kondo, Y., Komazaki, Y., Miyakawa, T., Jimenez, J. L., Jayne, J. T., Worsnop, D. R., Allan, J. D., and Weber, R. J.: Characterization of an Aerodyne aerosol mass spectrometer (AMS): Intercomparison with other aerosol instruments, Aerosol Sci. Tech., 39, 760-770, https://doi.org/10.1080/02786820500243404, 2005.

Tang, K., Page, J. S., and Smith, R. D.: Charge competition and the linear dynamic range of detection in electrospray ionization mass spectrometry, J. Am. Soc. Mass Spectr., 15, 1416-1423, https://doi.org/10.1016/j.jasms.2004.04.034, 2004.

Tannenbaum, E., Coffin, E. M., and Harrison, A. J.: The far ultraviolet absorption spectra of simple alkyl amines, J. Chem. Phys., 21, 311-318, https://doi.org/10.1063/1.1698878, 1953.

Usherenko, L. N., Fialko, M. B., Kumok, V. N., and Skorik, A. I.: Mechanism and kinetics of thermal-decomposition of ammonium oxalate, J. Appl. Chem. USSR, 61, 1559-1563, 1988.

Valentour, J. C., Aggarwal, V., and Sunshine, I.: Sensitive gas chromatographic determination of cyanide, Anal. Chem., 46, 924925, https://doi.org/10.1021/ac60343a048, 1974.

Veres, P., Gilman, J. B., Roberts, J. M., Kuster, W. C., Warneke, C., Burling, I. R., and de Gouw, J.: Development and validation of a portable gas phase standard generation and calibration system for volatile organic compounds, Atmos. Meas. Tech., 3, 683-691, https://doi.org/10.5194/amt-3-683-2010, 2010.

Veres, P. V., Roberts, J. M., Warneke, C., and deGouw, J.: Development of negative-ion proton-transfer chemical-ionization mass spectrometry (NI-PT-CIMS) for the measurement of gas-phase organic acids in the atmosphere, Int. J. Mass Spectrom., 274, 4855, https://doi.org/10.1016/j.ijms.2008.04.032, 2008.

Vieno, M., Heal, M. R., Twigg, M. M., MacKenzie, I. A., Braban, C. F., Lingard, J. J. N. Ritchie, S., Beck, R. C., A., M., Ots, R., DiMarco, C. F., Nemitz, E., Sutton, M. A., and Reis, S.: The UK particulate matter air pollution episode of March-April 2014: more than Saharan dust, Environ. Res. Lett., 11, 040440, https://doi.org/10.1088/1748-9326/11/4/044004, 2016.

Wang, S. C. and Flagan, R. C.: Scanning electrical mobility spectrometer, Aerosol Sci. Tech., 13, 230-240, https://doi.org/10.1080/02786829008959441, 1990.

Weber, R. J., Orsini, D., Daun, Y., Lee, Y. N., Klotz, P. J., and Brechtel, F. J.: A particle-into-liquid collector for rapid measurement of aerosol bulk chemical composition, Aerosol Sci. Tech. 35, 718-727, https://doi.org/10.1080/02786820152546761, 2001.

Wiedensohler, A.: An approximation of the bipolar charge distribution for particles in the sub-micron size range, J. Aerosol Sci., 19, 387-389, https://doi.org/10.1016/0021-8502(88)90278-9, 1988.

Williams, E. J., Baumann, K., Roberts, J. M., Bertman, S. B., Norton, R. B., Fehsenfeld, F. C., Springston, S. R., Nunnermacker, L. J., Newman, L., Olszyna, K., Meagher, J., Hartsell, B., Edgerton, E., Pearson, J. R., and Rodgers, M. O.: Intercomparison of ground-based $\mathrm{NO}_{y}$ measurement techniques, J. Geophys. Res.- 
Atmos., 103, 22261-22280, https://doi.org/10.1029/98JD00074, 1998.

Winer, A. M., Peters, J. W., Smith, J. P., and Pitts, J. N.: Response of commercial chemiluminescent nitric oxide-nitrogen dioxide analyzers to other nitrogen-containing compounds, Environ. Sci. Technol., 8, 1118-1121, https://doi.org/10.1021/es60098a004, 1974.

Womack, C. C., Neuman, J. A., Veres, P. R., Eilerman, S. J., Brock, C. A., Decker, Z. C. J., Zarzana, K. J., Dube, W. P., Wild, R. J., Wooldridge, P. J., Cohen, R. C., and Brown, S. S.: Evaluation of the accuracy of thermal dissociation CRDS and LIF techniques for atmospheric measurement of reactive nitrogen species, Atmos. Meas. Tech., 10, 1911-1926, https://doi.org/10.5194/amt10-1911-2017, 2017.
Xu, L. and Penner, J. E.: Global simulations of nitrate and ammonium aerosols and their radiative effects, Atmos. Chem. Phys., 12, 9479-9504, https://doi.org/10.5194/acp-12-94792012, 2012.

Yokelson, R. J., Griffith, D. W. T., and Ward, D. E.: Open path Fourier transform infrared studies of large-scale laboratory biomass fires, J. Geophys. Res., 101, 21067-21080, https://doi.org/10.1029/96jd01800, 1996.

Yokelson, R. J., Christian, T. J., Bertschi, I. T., and Hao, W. M.: Evaluation of adsorption effects on measurements of ammonia, acetic acid, and methanol, J. Geophys. Res., 108, 4649, https://doi.org/10.1029/2003JD003549, 2003. 